\title{
Impact of the Arctic Ocean Atlantic water layer on Siberian shelf hydrography
}

\author{
Igor A. Dmitrenko, ${ }^{1}$ Sergey A. Kirillov, ${ }^{2}$ L. Bruno Tremblay, ${ }^{3}$ Dorothea Bauch, ${ }^{1}$ \\ Jens A. Hölemann, ${ }^{4}$ Thomas Krumpen, ${ }^{4}$ Heidemarie Kassens, ${ }^{1}$ Carolyn Wegner, ${ }^{1}$ \\ Günther Heinemann, ${ }^{5}$ and David Schröder ${ }^{5}$ \\ Received 1 December 2009; revised 24 March 2010; accepted 6 April 2010; published 7 August 2010.
}

[1] This paper examines the role of the Arctic Ocean Atlantic water (AW) in modifying the Laptev Sea shelf bottom hydrography on the basis of historical records from 1932 to 2008, field observations carried out in April-May 2008, and 2002-2009 cross-slope measurements. A climatology of bottom hydrography demonstrates warming that extends offshore from the 30-50 m depth contour. Bottom layer temperature-time series constructed from historical records links the Laptev Sea outer shelf to the AW boundary current transporting warm and saline water from the North Atlantic. The AW warming of the mid-1990s and the mid-2000s is consistent with outer shelf bottom temperature variability. For April-May 2008 we observed on-shelf near-bottom warm and saline water intrusions up to the $20 \mathrm{~m}$ isobath. These intrusions are typically about $0.2^{\circ} \mathrm{C}$ warmer and $1-1.5$ practical salinity units saltier than ambient water. The 2002-2009 cross-slope observations are suggestive for the continental slope upward heat flux from the AW to the overlying low-halocline water (LHW). The lateral on-shelf wind-driven transport of the LHW then results in the bottom layer thermohaline anomalies recorded over the Laptev Sea shelf. We also found that polynya-induced vertical mixing may act as a drainage of the bottom layer, permitting a relatively small portion of the AW heat to be directly released to the atmosphere. Finally, we see no significant warming (up until now) over the Laptev Sea shelf deeper than 10-15 $\mathrm{m}$ in the historical record. Future climate change, however, may bring more intrusions of Atlantic-modified waters with potentially warmer temperature onto the shelf, which could have a critical impact on the stability of offshore submarine permafrost.

Citation: Dmitrenko, I. A., S. A. Kirillov, L. B. Tremblay, D. Bauch, J. A. Hölemann, T. Krumpen, H. Kassens, C. Wegner, G. Heinemann, and D. Schröder (2010), Impact of the Arctic Ocean Atlantic water layer on Siberian shelf hydrography, J. Geophys. Res., 115, C08010, doi:10.1029/2009JC006020.

\section{Introduction}

[2] It is believed that the eastern Siberian shelf is underlain by relic offshore submarine permafrost in an environment that is favorable for the stability of gas hydrates [e.g., Romanovskii et al., 2004, 2005]. Submarine permafrost and the permafrost-related gas hydrate stability zone are currently storing significant amounts of greenhouse gases, especially methane that has formed by the decomposition of gas hydrates at greater depth [Romanovskii et al., 2005]. The

\footnotetext{
${ }^{1}$ Leibniz Institute of Marine Sciences at University of Kiel (IFMGEOMAR), Kiel, Germany.

${ }^{2}$ Arctic and Antarctic Research Institute, St. Petersburg, Russia.

${ }^{3}$ Department of Atmospheric and Oceanic Sciences, Faculty of Science, McGill University, Montreal, Quebec, Canada.

${ }^{4}$ Alfred Wegener Institute for Polar and Marine Research, Bremerhaven, Germany.

${ }^{5}$ Department of Environmental Meteorology, Faculty of Geography/ Geosciences, University of Trier, Trier, Germany.

Copyright 2010 by the American Geophysical Union. 0148-0227/10/2009JC006020
}

dramatic reduction in summer Arctic sea ice extent and thickness in recent years [e.g., Comiso et al., 2008; Stroeve et al., 2008; Kwok and Rothrock, 2009; Kwok et al., 2009] has been accompanied by substantial warming of the Arctic Ocean Atlantic Intermediate Water (AW) transiting around the Eurasian Basin continental margins in a cyclonic sense [Schauer et al., 2004; Polyakov et al., 2007; Dmitrenko et al., 2008c]. This has wide significance for methane release from Arctic continental margins if increasingly warmer water enters from the Atlantic. Dissociation of hydrate in response to increased temperature has the potential to produce a rapid release of methane [Westbrook et al., 2009]. From these considerations the numerous speculations on shelf submarine permafrost degradation and liberation of methane have been discussed with emphasis on possible implication for further climate change [e.g., Reagan and Moridis, 2007; Shakhova et al., 2009; Shakhova and Semiletov, 2009; Westbrook et al., 2009].

[3] The eastern Siberian shelf, controlled by Siberian river discharge, ice formation/melting, and exchange with the Arctic Ocean and adjoining seas, represents the shallowest 


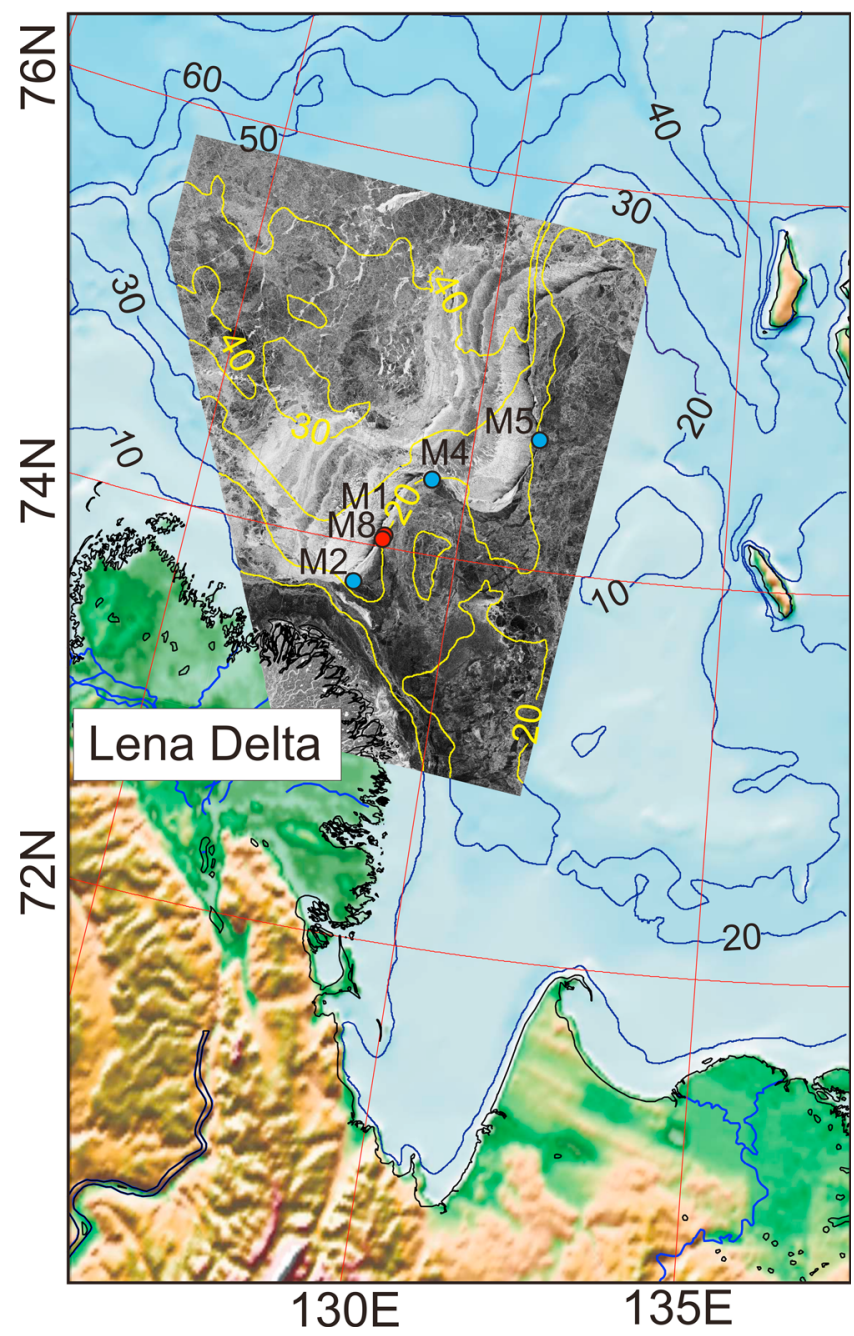

Figure 1. The southeastern Laptev Sea region with overlaid Environmental Satellite (ENVISAT) Advanced Synthetic Aperture Radar (ASAR) image from 1 May 2008. The gray and white strips are associated with newly formed 5-30 cm thick columnar sea ice. The black narrow strip further onshore indicates the open water that separates the land-fast ice to the southeast (dark gray color) from the newly formed sea ice to the northwest. Some ambiguity in the interpretation of newly formed sea ice and surrounding older fraction may occur. The blue and red dots mark moorings deployed along the land-fast ice edge in April-May 2009. Blue dots identify automatic weather station (AWS) positions. The bathymetric contours (in meters) are shown by blue and yellow solid lines.

shelf region of the entire Arctic Ocean (with an average depth of about 20-30 m) extending at a distance of 400 $800 \mathrm{~km}$ from the shoreline. In contrast, the Beaufort and Chukchi shelves are about 50 to $100 \mathrm{~m}$ deep and constitute a rather narrow Arctic shelf region. Past hydrographic work on the eastern Siberian shelf seas took place primarily on the more easily accessible mid and inner shelves composing approximately $20 \%$ of the total Arctic Ocean surface area [e.g., Dmitrenko et al., 2001; Wegner et al., 2005; Bauch et al., 2009a, 2009b; Dmitrenko et al., 2009]. Compara- tively, the outer shelf region with depth ranging from 50 to $100 \mathrm{~m}$ received less attention. A look at water properties northward of the eastern Siberian shelf shows why consideration of the outer shelf is warranted. The upper boundary of AW defined by the $0^{\circ} \mathrm{C}$ isotherm lies just beneath the Siberian shelf break $(\sim 100 \mathrm{~m})$ at a depth of $120-160 \mathrm{~m}$. This water, compared to ambient shelf waters, is relatively warm and saline. It enters the Arctic Ocean through Fram Strait and the Barents Sea shelf, and the branches merge just north of the Kara Sea [Aagaard, 1989; Rudels et al., 1994]. The AW then finds its level of equilibrium at an intermediate level of 150$900 \mathrm{~m}$ and mixes vigorously, while transiting around the Eurasian Basin in a cyclonic sense as a narrow topographically trapped boundary current with a warm core located 50 to $300 \mathrm{~km}$ off the Siberian shelf break [Schauer et al., 2002]. During this transport the long-term mean AW core temperature decreases from 2.5 to 3.0 near Svalbard down to $1{ }^{\circ} \mathrm{C}$ northward of New Siberian Islands [Dmitrenko et al., 2008c]. This decrease in temperature provides evidence that some fraction of the AW heat is lost because of lateral and vertical heat exchange.

[4] Wind-forced upwelling littoral flux of warm and saline AW onto the continental shelves of the Chukchi and Beaufort Seas in the western Arctic Ocean is commonly observed [e.g., Pickart et al., 2009]. It is particularly pronounced in the three major canyons that cut into these shelves, namely, Barrow and Herald Canyons in the Chukchi Sea and Mackenzie Canyon in the Beaufort Sea (for overview see Pickart et al. [2009]). Away from these canyons, upwelling has also been observed along the continental margin of the Canada Basin [e.g., Pickart, 2004; Nikolopoulos et al., 2009; Pickart et al., 2009].

[5] In contrast to the Canada Basin continental margins, there are no reports of the inflow of the warm and saline AW onto the eastern Siberian shelf except for speculation of its existence by Dmitrenko et al. [2001], on the basis of scarce measurements taken in the eastern Laptev Sea in 19981999. In general, the Siberian shelf has never been considered as a possible location for the ventilation of AW heat, and there exists no estimates of the AW heat lost associated with potential AW migration onto the shelf.

[6] Owing to specifics of off-slope AW mass structure, the shelf-basin interaction is of special significance for the Siberian shelf. The main goal of this paper is to examine the Laptev Sea shelf bottom layer hydrography in the context of shelf-basin interaction with AW with potential implication for the stability of the submarine permafrost and permafrostrelated gas hydrate stability zone. This paper is motivated by evidences of on-shelf inflow of warm and saline water as observed by moored instruments and by the conductivitytemperature-depth (CTD) profiling in the vicinity of the Lena Delta in the southeastern Laptev Sea (Figure 1) between April and May 2008. In this paper we show unequivocal evidence of Atlantic-modified water incursions on the outer and mid shelf in the Laptev Sea, and we argue that the incursions may also extend all the way to the inner shelf. Recent measurements made in the Laptev Sea, however, also show warmer water masses from autumn vertical mixing present in this location, preventing at this point a clear attribution of the inner shelf change in hydrography to AW incursions. These newly obtained results prompt us to revisit the Russian historical hydrographic data set for 1932-2008 in order to 
delineate the onshore extension of the AW impact on the shelf hydrography as well as the water temperature anomalies associated with AW incursion on the shelf and those associated with climatic changes occurring in the region.

[7] The paper is structured as follows. Section 2 presents a brief description of the historical hydrographic data (section 2.1), along with observations carried out at the Laptev Sea shelf in April-May 2008 (section 2.2), and background hydrography and methods applied to analyze the historical data (section 2.3). Section 3.1 documents the bottom layer hydrography and its multidecadal variability in the Laptev Sea mid and outer shelves using historical (1932-2008) data. In section 3.2 we present evidence for the on-shelf inflow of warm and saline waters of AW origin, using AprilMay 2008 inner and mid shelf hydrographic observations. Section 4 combines our inferences from the historical data, 2008 shelf observations, and 2002-2009 cross-slope data to emphasize the role of the AW in modifying the shelf water properties. We also discuss obtained results in the context of climate change. Section 5 summarizes our conclusions.

\section{Data and Methods}

[8] The first data set considered in this study is the Arctic and Antarctic Research Institute (AARI) hydrographic data set, which consists of summer and winter temperature and salinity observations (1932-1992) updated with recent summer and winter measurements from 1993 to 2008 . The second data set consists of temperature, salinity, and velocity measurements from CTD profiling and moored instruments collected during the Russian-German TRANSDRIFT XIII expedition in the Laptev Sea coastal polynya area in AprilMay 2008. In addition, we describe methods used for historical data processing. In the following, we identify subregions on the Eurasian shelf where incursions of Atlantic-modified water are present. These are identified by examining the long-term mean bottom temperature and salinity as well as salinity-depth and temperature-depth scatterplots derived from the historical bottom temperature and salinity observations.

\subsection{Historical Hydrographic Data}

[9] Winter historical hydrographic data from 1503 stations were obtained during Soviet aircraft surveys from March to May in the 1960s-1990s and more recently from the RussianGerman TRANSDRIFT expeditions in 1996, 1999, and 2008. Summer ship-based observations (6334 stations) were collected in the ice-free regions of the Laptev Sea in AugustSeptember 1932-2008 (see Dmitrenko et al. [2008b] for spatial and temporal coverage before 2006). From this data set two subsets were derived for subregions located on the outer shelf (subregion 1, from 50 to $100 \mathrm{~m} \mathrm{depth)}$ and the mid shelf (subregion 2, from 30 to $50 \mathrm{~m}$ depth); see Figure 2. The outer shelf subset consists of 175 winter and 720 summer stations. The mid shelf subset consists of 122 winter and 997 summer stations. The hydrographic measurements cover almost the entire period from 1960 to 2008 for both subregions.

[10] Prior to 1993, Nansen bottles were used and salinity was measured with a Russian GM-65 salinometer with an accuracy of 0.05 practical salinity units (psu). Temperature was measured by mercury-reversing thermometers with an accuracy of $0.02^{\circ} \mathrm{C}$. In recent years, data came from CTD measurements with a salinity and temperature accuracy greater than $0.01 \mathrm{psu}$ and $0.005^{\circ} \mathrm{C}$, respectively. The summer-to-winter hydrographic surveys cover the entire thirty-year period from 1963 to 1993.

[11] For comparison to the historical data, we also use the CTD data from a cross-slope transect (Figures 2a and 2b) deployed during icebreaker Kapitan Dranitsyn (2002-2006 and 2008-2009) and R/V Viktor Buinitsky (2007) Nansen and Amundsen Basins Observational System (NABOS) cruises in August-October using a shipboard SBE19+ CTD. In 2008-2009, this transect was complemented by two CTD profiles taken over the shelf break from R/V Ivan Kireev (September 2008, expedition TRANSDRIFT XIV) and R/V Yakov Smirnitsky (September 2009, expedition TRANSDRIFT XVI) using a similar type CTD.

\subsection{Data From April-May 2008}

[12] As a part of the Russian-German project Laptev Sea System, a fieldwork program was conducted in the Laptev Sea coastal polynya region to study the response of the shelf hydrography to the presence of persistent open water during the cold season. Between April and May 2008 five moorings were deployed 10 to $800 \mathrm{~m}$ distance from the fast ice edge contouring the onshore perimeter of the West New Siberian (WNS) coastal polynya (Figure 1). All moorings carried a combination of $300 \mathrm{kHz}$ downward-looking Workhorse Sentinel Acoustic Doppler Current Profilers (ADCPs) by Teledyne RD Instruments and Sea-Bird Electronics Inc. SBE 37s with CTD sensors. The SBE 37s provided one-minute interval conductivity, temperature, and pressure at fixed depths sampling the surface $(\sim 4.5 \mathrm{~m})$ and bottom $(17-21 \mathrm{~m})$ water layers. The velocity data from the ADCPs were taken at $1 \mathrm{~m}$ depth intervals, with a $5 \mathrm{~min}$ ensemble time interval and 60 pings per ensemble. The first and last valid bins were located at depth of about $5.5 \mathrm{~m}$ and $17.5 \mathrm{~m}$, respectively. All moorings were anchored at $\sim 20 \mathrm{~m}$ water depth (Figure 1). This paper focuses on the results of the M1 and M2 moorings deployed for 10-28 April and 11 April to 5 May 2008, respectively, approximately 10 to $50 \mathrm{~m}$ distance from the fast ice edge. Because of technical problems with SBE 37 conductivity sensors on M4 and M5, no reliable salinity records were obtained. Mooring-based observations were complemented by CTD profiling taken episodically at the mooring positions and from the pack ice using a SBE19+ CTD. Routine CTD observations were carried out from the 40 to $170 \mathrm{~cm}$ thick ice cover, with the instrument lowered through a hole $22 \mathrm{~cm}$ in diameter. According to the manufacturers' estimates, individual temperature and conductivity measurements are accurate to $\pm 0.005^{\circ} \mathrm{C}$ and $\pm 0.0005 \mathrm{~S} / \mathrm{m}$, respectively, for the SBE $19+$, and $\pm 0.002^{\circ} \mathrm{C}$ and $\pm 0.0003 \mathrm{~S} / \mathrm{m}$ for the SBE $37 \mathrm{~s}$. The ADCP velocity precision and resolution are $\pm 0.5 \%$ and $\pm 0.1 \mathrm{~cm} / \mathrm{s}$, respectively. The ADCP velocity estimated error was $1.8 \mathrm{~cm} / \mathrm{s}$. Compass accuracy is $\pm 2.7^{\circ}$. The current direction was corrected by adding the mean magnetic deviation $\left(-16^{\circ}\right)$. All CTDs were calibrated before the expedition.

[13] In order to monitor the geographical extent of the WNS coastal polynya, Environmental Satellite (ENVISAT) Advanced Synthetic Aperture Radar (ASAR) images were acquired between April and May 2008. The ENVISAT ASAR images, using the $\mathrm{C}$ band frequency, were acquired 

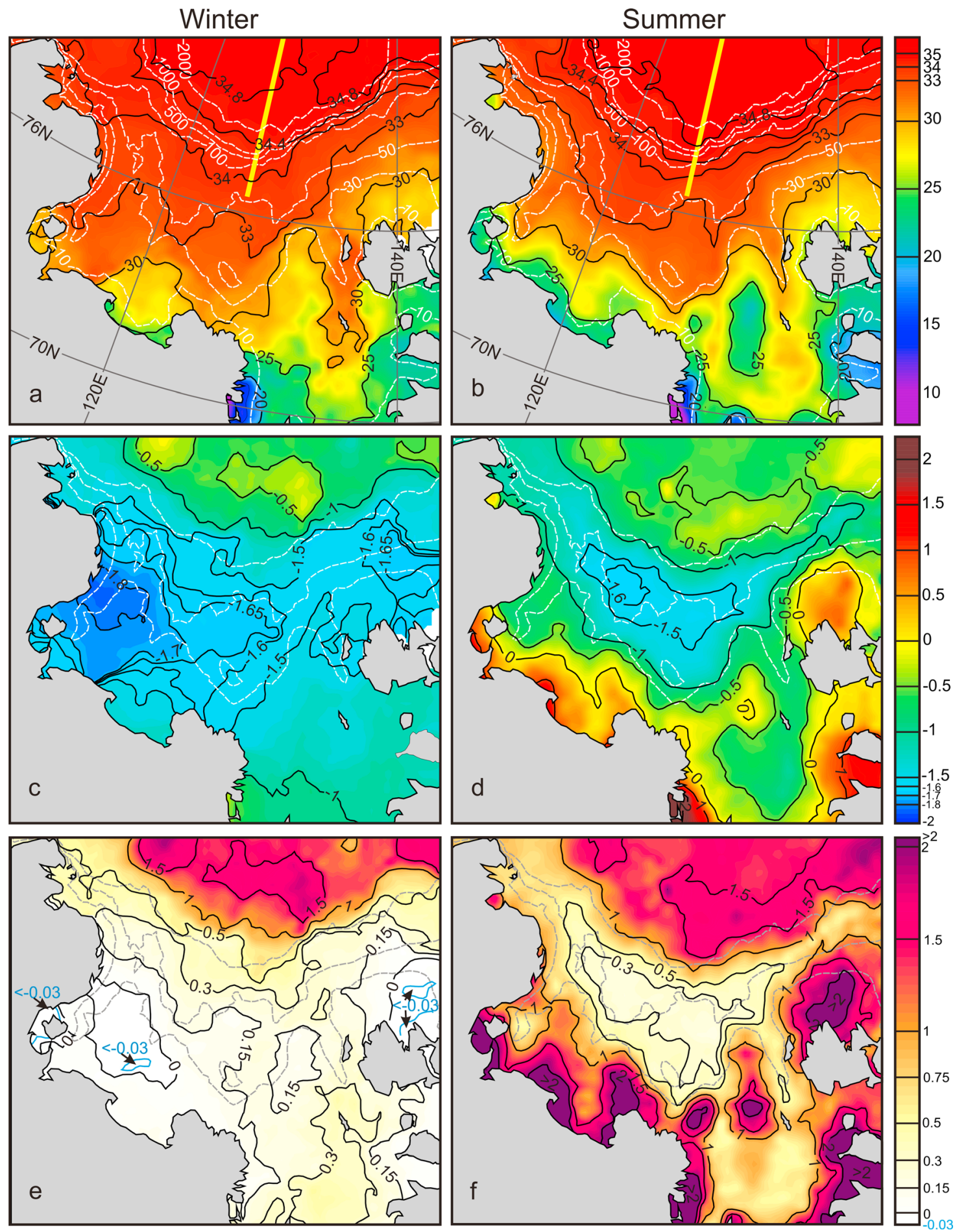

Figure 2. The long-term mean (1930s-2000s) (a, b) bottom salinity (practical salinity units (psu)), (c, d) temperature $\left({ }^{\circ} \mathrm{C}\right)$, and $(\mathrm{e}, \mathrm{f})$ difference between the observed and the freezing temperature $\left({ }^{\circ} \mathrm{C}\right)$ for winter and summer. Dashed lines show the 10, 30, 50, 100, 500, 1000, and $2000 \mathrm{~m}$ depth contours. Subregion 1 (outer shelf) occupies the area between 50 and $100 \mathrm{~m}$ depth. Subregion 2 (mid shelf) covers the area between 30 and $50 \mathrm{~m}$. The yellow line on the top indicates CTD cross-slope transect occupied annually in August-October from 2002 to 2009.

in a single vertical transmit and receive (VV) polarization configuration and in Wide Swath Mode. They cover an area of approximately $400 \times 800 \mathrm{~km}$ square, with a pixel spacing of $150 \mathrm{~m}$ and a spatial resolution of $\sim 300 \mathrm{~m}$. The meteo- rological observations were carried out at three mooring positions (Figure 1) using an automatic weather station (AWS). Data of air temperature, humidity, horizontal wind vector, net radiation, and barometric pressure were recorded 


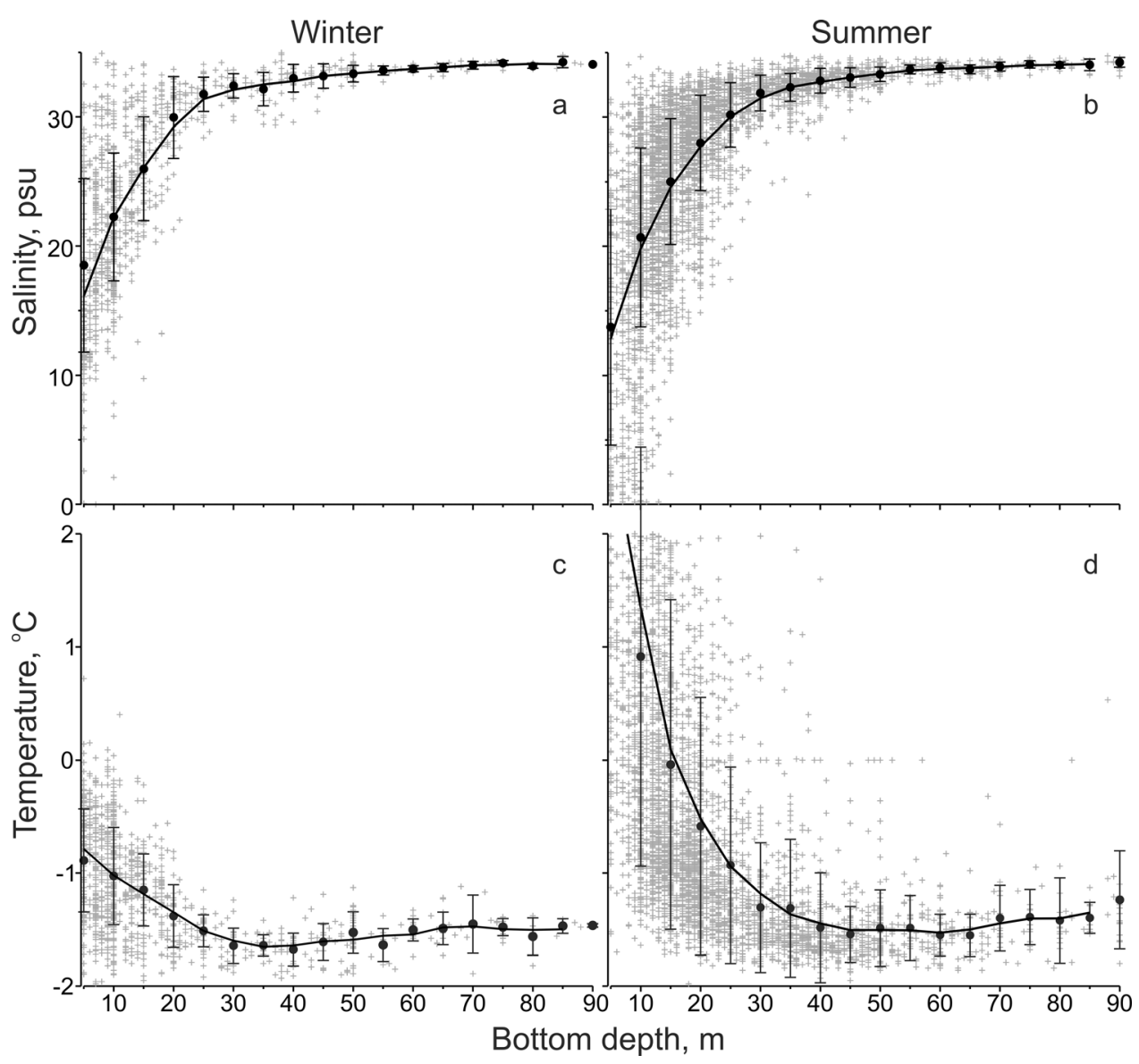

Figure 3. (a, b) Salinity-depth and (c, d) temperature-depth scatterplots for all winter and summer snapshot temperature and salinity measurements near the seafloor. Error-barred dots show the long-term mean with standard deviation. The solid line indicates the three-point running average. Note that Figure $3 \mathrm{~d}$ shows only the temperatures cooler than $2^{\circ} \mathrm{C}$.

every 10 min. Because of polar bear attacks, the M2 AWS data were lost beginning 23 April. In order to fill this gap we use the $40 \mathrm{~km}$ resolution Global Digital Analyses of the German Meteorological Service called GME [Majewski et al., 2002]. The GME data were validated using the AWS data. Results show that the GME is in reasonable agreement with in situ measurements for the atmospheric pressure and wind fields (correlation coefficients 0.8-0.9; see also section 3.2) and can be utilized for our study.

\subsection{Background Hydrography and Methods of Historical Data Processing}

[14] The Laptev Sea long-term mean bottom temperature and salinity are compiled in order to access the background patterns of the Laptev Sea bottom hydrography and to delineate subregions that are likely affected by interaction with the Arctic Ocean intermediate AW layer. For each summer and winter season the historical temperature and salinity measurements from 1932 to 2008 were linearly interpolated using data from a $120 \mathrm{~km}$ search radius onto a regular grid with horizontal and vertical resolution of $50 \mathrm{~km}$ and $1 \mathrm{~m}$, respectively. The long-term mean bottom temperature, salinity, and offset from freezing temperature were computed at each node over the 1932-2008 time period (Figure 2). The freezing temperature was calculated using a standard algorithm by Fofonoff and Millard [1983] with the input of in situ depth and salinity.

[15] Figure 2 shows the main features of the Laptev Sea bottom hydrography. During summer the Siberian shelf hydrography is forced by river runoff and ice melting, resulting in substantial bottom layer warming and freshening (Figures 2b, 2d, and 2f). In contrast, thermodynamic ice formation provides cooling and salt input to the bottom layer through brine release during winter (Figures $2 \mathrm{a}, 2 \mathrm{c}$, and 2e). These processes mainly dominate the inner shelf and partly dominate the mid shelf (Figure 2). Furthermore, Figure 2 reveals general tendency of warming and salinification of the bottom water with distance offshore over the area deeper than $30-50 \mathrm{~m}$, where no significant seasonal variability is observed. Among all key processes, controlling Siberian outer shelf hydrography, only the on-shelf near-bottom intrusion of the warm and saline water from the AW boundary current is capable of providing a warmer and saltier signal that is very distinct from the thermohaline signals imposed by all other potential contributors. Figure 2 clearly shows that this signal almost entirely controls the outer shelf and may also affect the mid shelf. Below we define the range of depth in which the warmer and saltier signal imposed by interaction with AW keeps its thermohaline identity by examining our historical data. 


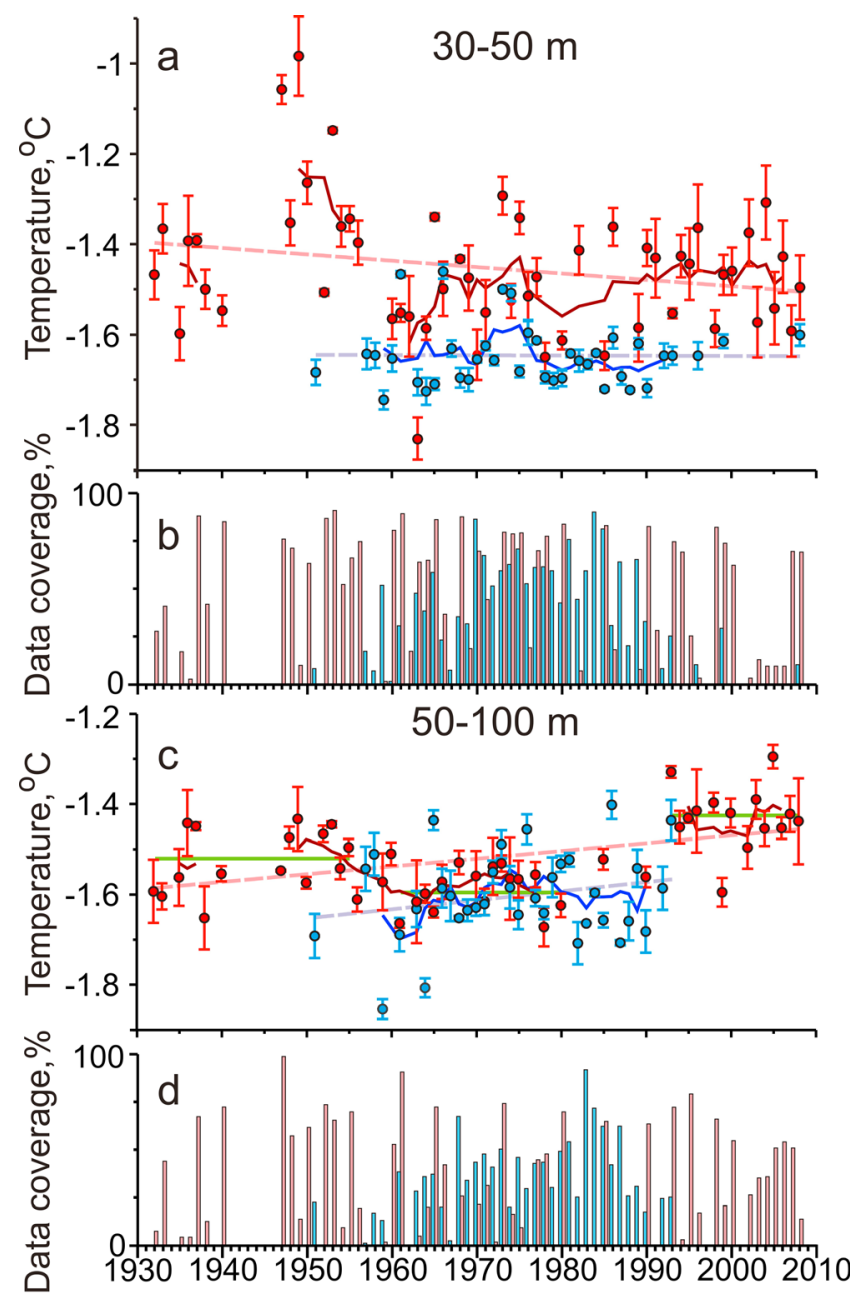

Figure 4. Time series of the summer (red dots) and winter (blue dots) seasonal mean bottom layer temperature $\left({ }^{\circ} \mathrm{C}\right)$ calculated over (a) the mid shelf $(30-50 \mathrm{~m})$ and (c) the outer shelf $(50-100 \mathrm{~m})$. (b, d) The data coverage of the interpolated field (percent from the entire domain area) over these subregions with pink and blue for summer and winter, respectively. Error bars indicate the bottom layer temperature estimation error, which is due to limited data coverage, and the standard error calculated from temperature measurements (see Dmitrenko et al. [2008b] for more details). Bold lines indicate five-year running mean. Green horizontal lines show 15-year means. Dashed lines indicate linear trends.

[16] For our investigation of AW interaction on the shelf we use salinity-depth and temperature-depth scatterplots (Figure 3) derived from the historical bottom temperature and salinity observations during summer and winter. Figure 3 reveals a tendency for bottom temperature to increase with depth below $\sim 30 \mathrm{~m}$ during winter and $\sim 50 \mathrm{~m}$ during summer, which is accompanied by an increase in salinity and therefore is likely associated with the AW impact. In fact, Figure 3 shows patterns that are consistent with Figure 2. The range of temperature increase from 30 to $100 \mathrm{~m}$ depth by $\sim 0.2^{\circ} \mathrm{C}$ is less than the seasonal mean temperature standard deviation of $0.32^{\circ} \mathrm{C}$ for summer (Figure 3d) and exhibits almost no seasonal variability (Figures $3 \mathrm{c}$ and $3 \mathrm{~d}$ ). The sea- sonal difference in warm and saline water on-shelf penetration by $\sim 20 \mathrm{~m}$ depth seems not statistically significant (Figures 3c and 3d). On the basis of Figure 3, we define two subregions that are likely affected by AW. The first is the outer shelf, deeper than $50 \mathrm{~m}$ and shallower than $100 \mathrm{~m}$ (subregion 1), which exhibits thermohaline patterns that are clearly attributable to an AW impact. The second is the mid shelf, delineated by depth contours between $30 \mathrm{~m}$ and $50 \mathrm{~m}$ (subregion 2), which is influenced by both AW and seasonal sea ice formation.

[17] The 1930s-2000s time series of annual mean summer and winter bottom layer salinity and temperature over the Laptev Sea mid and outer shelves are calculated by integrating the annual summer and winter salinity field over a $10 \mathrm{~m}$ bottom layer in the shelf area with depth ranging between 30 and $50 \mathrm{~m}$, and 50 and $100 \mathrm{~m}$ depth contours, respectively. This approach was motivated by the fact that significant differences in spatial patterns within these two regions were observed (Figure 2). The method used to integrate the salinity and temperature over a regular grid ( $x, y$, and $z$ ) follows that of Dmitrenko et al. [2008a]. The statistical error of the annual values (Figure 4) reflects both the scaling error, which is due to the limited data coverage (see Figures $4 \mathrm{~b}$ and $4 \mathrm{~d}$ ), and the standard error calculated from the temperature measurements (for more details see Dmitrenko et al. [2008a]). Differences in station locations and spatial data coverage from year to year significantly complicate the interpretation of the derived time series shown in Figure 4. A five-year running mean is applied to filter the noise associated with the limited data coverage and the errors attributed to the scaling procedure. The conclusions presented hereafter focus mainly on lower-frequency variability and are insensitive to the exact number of years used in the running average.

[18] The resulting bottom layer temperature-time series composed of the five-year running mean of summer and winter time series are shown in Figure 5. The annual mean was obtained by averaging winter and summer data. For those years when summer or winter data is missing, the existing value is corrected by the seasonal temperature amplitude derived from the summer and winter long-term mean of $-1.52^{\circ} \mathrm{C}$ and $-1.60^{\circ} \mathrm{C}$ for subregion 1 , and $-1.45^{\circ} \mathrm{C}$ and $-1.64^{\circ} \mathrm{C}$ for subregion 2 .

\section{Results}

\subsection{Hydrography of the Laptev Sea Bottom Layer: Analysis of Historical Data}

[19] Here we examine the bottom layer temperature and salinity spatial distribution (Figure 2) and the mean bottom temperature-time series (Figure 4) retrieved for the Laptev Sea subregion 1 and 2 shown in Figure 2. In addition, we identify processes that control the bottom temperature interannual variability by examining the atmospheric and hydrographic forcing.

[20] During both summer and winter the relatively cold bottom water of $-1.5^{\circ} \mathrm{C}$ to $-1.8^{\circ} \mathrm{C}$ extends zonally, isolating the warm and saline outer shelf from the warm and fresh inner shelf (Figures 2a, 2b, 2c, and 2d). During winter a bottom layer cooling down to or below freezing is observed in the western Laptev Sea between $73^{\circ} \mathrm{N}$ and $76^{\circ} \mathrm{N}$ and north of the New Siberian Islands at about $77^{\circ} \mathrm{N}$ and $140^{\circ} \mathrm{E}$ 


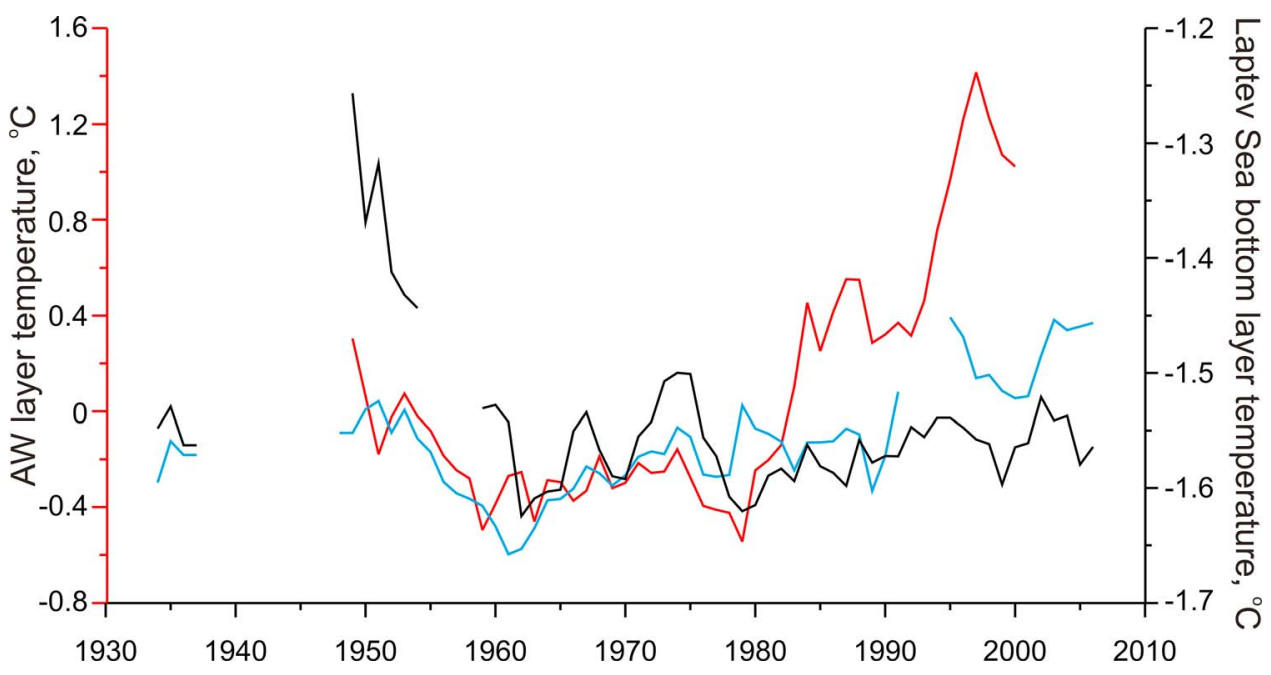

Figure 5. Five-year running mean of the annual mean bottom layer temperature $\left({ }^{\circ} \mathrm{C}\right)$ over the mid shelf (30-50 m, black line) and the outer shelf (50-100 m, blue line). The red line shows the five-year running mean from the AW layer temperature by Polyakov et al. [2004].

(Figures 2c and 2e). We attribute the presence of these cold waters to coastal polynya activity. In the summer, the inner shelf seabed water temperature increases to about $2^{\circ} \mathrm{C}$. These waters properties are vertically homogeneous and are primarily affected by solar radiation heating and river runoff (Figures $2 \mathrm{~d}$ and $2 \mathrm{f}$ ). Winter ice formation mostly dominates the transitional area between the inner and mid shelves over depths ranging from 10 to $30 \mathrm{~m}$, resulting in a seasonal salinity increase by $\sim 3-5$ psu (Figures $2 \mathrm{a}$ and $2 \mathrm{~b}$ ). In winter, the saltier water occupies the submarine valleys over the eastern Laptev Sea (Figure 2a; see also Figure 1 for detailed bottom topography). In contrast to the inner and mid shelves, the outer shelf exhibits weak seasonal variability (Figures 2a, 2b, 2c, and 2d).

[21] The mid and outer shelves are also characterized by the lowest interannual variability. For example, temperature standard deviations between depths of 30 to $100 \mathrm{~m}$ are $0.2^{\circ} \mathrm{C}-$ $0.4^{\circ} \mathrm{C}$ and $0.2^{\circ} \mathrm{C}-0.1^{\circ} \mathrm{C}$ for summer and winter, respectively. At depths larger than $100 \mathrm{~m}$, the standard deviation rises up to $0.5^{\circ} \mathrm{C}-0.9^{\circ} \mathrm{C}$ for both winter and summer. Over the inner shelf (less than $30 \mathrm{~m}$ ), the summer bottom temperature standard deviation is $1^{\circ} \mathrm{C}-3^{\circ} \mathrm{C}$ with maximal values observed over the shoals and near the coastline, while during winter the bottom temperature standard deviation is less than $0.1^{\circ} \mathrm{C}-0.2^{\circ} \mathrm{C}$. In fact, the salinity-depth and temperaturedepth scatterplots shown in Figure 3 demonstrate patterns that are consistent with above-described regularities.

[22] The bottom temperature-time series (Figures $4 \mathrm{a}$ and 4c) reveal characteristic features of the bottom layer interannual variability. For the outer shelf we calculate the longterm mean bottom temperature to be $-1.52^{\circ} \mathrm{C}$ for summer and $-1.60^{\circ} \mathrm{C}$ for winter, with standard deviations of $0.09^{\circ} \mathrm{C}$ and $0.10^{\circ} \mathrm{C}$, respectively. For the mid shelf the long-term mean bottom temperature is $-1.45^{\circ} \mathrm{C} \pm 0.15^{\circ} \mathrm{C}$ and $-1.64^{\circ} \mathrm{C} \pm$ $0.07^{\circ} \mathrm{C}$ for summer and winter, respectively. The multidecadal variability of the bottom temperature is of particular interest. The outer shelf summer bottom temperature shows two relatively warm periods from the late 1930 s to $1950 \mathrm{~s}$ (with a data gap in the 1940s) and in the 1990s-2000s, and one cold period in the 1960s-1980s (Figure 4c). The differences between the 15-year averages of the bottom temperature peaks (horizontal lines in Figure 4c) emphasize different thermal conditions during warm and cold periods. In contrast, the mid shelf demonstrates only one distinctly warmer period in the 1950s. The winter records are too short to provide any consistent conclusions.

[23] The five-year running mean temperature-time series (Figure 5) are calculated to identify processes that control the bottom temperature multidecadal variability. We argue that the outer shelf is predominantly controlled by the interaction with AW. There are several pieces of evidence supporting this hypothesis. First, a positive correlation $(0.45)$ is found between the outer shelf bottom salinity (not shown) and temperature-time series. This correlation (and others presented later) is statistically significant at the $95 \%$ confidence level (for the mid shelf no statistically significant correlation is revealed). This is a typical signature of the AW inflow. Second, the same warmer and cooler periods stand out over the outer shelf bottom layer (Figure 4c) as for the AW core temperature anomalies revealed by Polyakov et al. [2004] from the regional AW core temperature anomalies normalized by their respective regional standard deviations and averaged over the ten subregions covering the entire Arctic Ocean. Furthermore, the outer shelf bottom temperature positively correlates with the five-year running mean from the AW core temperature-time series by Polyakov et al. [2004] (0.74) and the Arctic Oscillation (AO) indexes $(0.47)$. The correlation 0.74 is statistically significant at the $95 \%$ confidence level even for the effective number of degrees of freedom $N=5$ (number of points in the running mean). Note that AO also correlates with AW core temperature by Polyakov et al. [2004] (0.60), underlining the wind-driven origin of the AW inflow into the Arctic Ocean [e.g., Dickson et al., 2000]. The outer shelf bottom temperature also correlates with the summer zonal wind (0.46), implying the role of wind-driven flow of the Atlanticmodified water onto the shelf discussed in section 4. In contrast, all other potential local contributors (surface air 
temperature, local atmospheric vorticity and meridional wind, river discharge, the Laptev Sea fresh water content anomalies [Dmitrenko et al., 2008b], and sea ice production [Dmitrenko et al., 2009]) exhibit no statistically significant correlation with the outer shelf bottom temperature. Overall, this implies that the outer shelf is remotely controlled by the AW inflow into the Arctic Ocean from the North Atlantic with contribution of local wind-driven Atlantic-modified water on-shelf inflow.

[24] In contrast to the outer shelf, the mid shelf is entirely dominated by local atmospheric forcing and sea ice formation during winter. In fact, the mid shelf bottom temperature exhibits no statistical linkage with the AW (Figure 5). Instead, it correlates with the winter mean local atmospheric vorticity $(0.55)$, meridional wind $(-0.49)$, and zonal wind (0.67). This is in agreement with the positive correlation of 0.53 between the mid shelf bottom salinity (not shown) and the Laptev Sea shelf sea ice production estimates by Dmitrenko et al. [2009]. Under this scenario, the offshore southerly winds during winter result in water cooling and salinification due to more intense ice formation, and alongshore westerly wind results in warm water on-shore flow from the outer shelf. Note, however, that no correlation between the mid shelf salinity and temperature is present. This allows no clear attribution of the temperature and salinity changes to be made. This, in turn, reflects the complexity of the mid shelf environment, which is likely impacted by interaction with both the outer and the inner shelves.

\subsection{Bottom Hydrography Patterns Over the Laptev Sea Mid and Inner Shelves: Analysis of the Field Data From April to May 2008}

[25] Here we show evidences of lateral on-shore nearbottom inflow of warmer and saltier waters onto the Laptev Sea mid and inner shelves. Our examination is based on CTD areal profiling and CTD and velocity measurements from moored instruments deployed between April and May 2008 over the coastal polynya area in the vicinity of the Lena Delta in the southeastern Laptev Sea (Figure 1). In addition, we attempt to identify the pathways of the warmer and saltier bottom layer anomalies and processes that control the bottom layer hydrography by examining the local atmospheric and sea ice forcings.

[26] The Laptev Sea continental shelf is known for active water mass transformation in winter due to seasonal sea ice formation (Figure 2). The offshore components of winter surface wind forcing over the Eurasian coast create persistent areas of open water and young ice downwind of the land-fast ice in the absence of sensible ocean heat input from below [Martin and Cavalieri, 1989; Bareiss and Görgen, 2005]. During winter the extensive stretches of open water (up to $200 \mathrm{~km}$ wide), known as the Great Siberian Polynya, combined with extremely low air temperatures, induce intensive thermodynamic ice formation. This provides a strong salt input to the underlying shelf water because of brine release (Figures $2 \mathrm{a}$ and $2 \mathrm{~b}$ ) and gives rise to seasonal salinity changes [Dmitrenko et al., 2008b, 2009].

[27] The system of coastal polynyas over the southeastern Laptev Sea in April 2008 was not very well developed prior to the last ten days of April, as shown in the ENVISAT ASAR imagery (Figure 6). The National Centers for Environmental Prediction (NCEP), GME, and AWS surface wind data (Figure 7) indicate that three polynya-favorable easterly-southeasterly wind events were observed between 16 and 18 April (with winds up to $5-7 \mathrm{~m} / \mathrm{s}$ ), between 22 and 23 April (up to $10 \mathrm{~m} / \mathrm{s}$ ), and between 26 and 30 April (up to $12 \mathrm{~m} / \mathrm{s}$ ). The first wind event was not sufficient to create polynya opening, while the second and mainly the third event resulted in opening of a polynya covered with frazil ice in the first $20 \mathrm{~km}$ and columnar new ice in the next 40 $50 \mathrm{~km}$ wide. This polynya is clearly evident in the satellite scenes from the last ten days of April (Figure 6).

[28] The CTD profile from station 14 (21 April 2008) located in the pack ice seaward of the polynya area (Figure 8a) exhibits a warmer (by $0.23^{\circ} \mathrm{C}$ ) and saltier (by $1.2 \mathrm{psu}$ ) bottom water layer deeper than $26 \mathrm{~m}$ well before the polynya started to form. Station 13 taken the same day along the fast ice edge $\sim 17.5 \mathrm{~km}$ to the east of station 14 (see Figure 6 for station positions) shows warmer (by $0.05^{\circ} \mathrm{C}$ ) and saltier (by $0.45 \mathrm{psu}$ ) bottom layer waters from depth ranging between 13 and $19 \mathrm{~m}$ (not shown). At station 16 (Figure 8b) taken on 24 April, the same patterns in bottom temperature and salinity are observed before the major end-of-April polynya event occurred. These profiles provide evidence that the warmer and saltier bottom layer had already occupied the mid shelf area before the major polynya opening during the end of April.

[29] The CTD profiles taken at mooring location M1 before its deployment and after its recovery show inflow of warmer and saltier bottom water, which occurred during the period of mooring observations (Figure 9). At M1 deployment (station 1, 10 April 2008), the bottom layer temperature and salinity was $-1.63^{\circ} \mathrm{C}$ and $31 \mathrm{psu}$. At the recovery (station 20, 28 April) the bottom layer was $0.13^{\circ} \mathrm{C}$ warmer and $0.8 \mathrm{psu}$ saltier (Figure 9a). The warmer and saltier bottom mixed layer occupied the $2.5 \mathrm{~m}$ thick water layer above the seafloor (Figure 9a). When mooring M2 was recovered (station 25, 5 May), the bottom mixed layer of $\sim 7 \mathrm{~m}$ thick was $0.07^{\circ} \mathrm{C}$ warmer and $0.5 \mathrm{psu}$ saltier when compared with station 15 at the same M2 location on 24 April 2008 (Figure 9b). The vertical distribution of turbidity demonstrates that thickening and intensification of the bottom nepheloid layer originated from resuspension of bottom sediments by turbulent flow [Wegner et al., 2005]. This is in line with warm and saline bottom layer incursion onto the shelf (Figure 9). This is indirect evidence for the advective origin of the bottom layer temperature inversion.

[30] The bottom layer time series of 24-hour mean temperature and salinity shown in Figures 10a (M1) and 11a (M2) exhibit variability that is consistent with vertical CTD profiling. Figures $10 \mathrm{~b}$ and $11 \mathrm{~b}$ show the time series of near-bottom residual currents at $\mathrm{M} 1$ and $\mathrm{M} 2$, respectively, obtained by a 25-hour low-pass filtering of horizontal velocity components. For M1, during the first two days after deployment (10-12 April) the temperature and salinity were negatively correlated and had a mean of about $-1.62^{\circ} \mathrm{C}$ and $30.2 \mathrm{psu}$, respectively (Figure 10c). From 12 April this pattern changed to positive correlation, with temperature and salinity increasing by $0.08^{\circ} \mathrm{C}$ and $1.4 \mathrm{psu}$ (Figures $10 \mathrm{a}$ and 10c). This change has been accompanied by northwesterly flow. Following this event, the bottom layer equilibrated at a new warmer and saltier state of about $-1.53^{\circ} \mathrm{C}$ and $31.7 \mathrm{psu}$ (Figure 10a). This equilibrium, however, has been disrupted by three southeasterly wind events favorable for polynya 

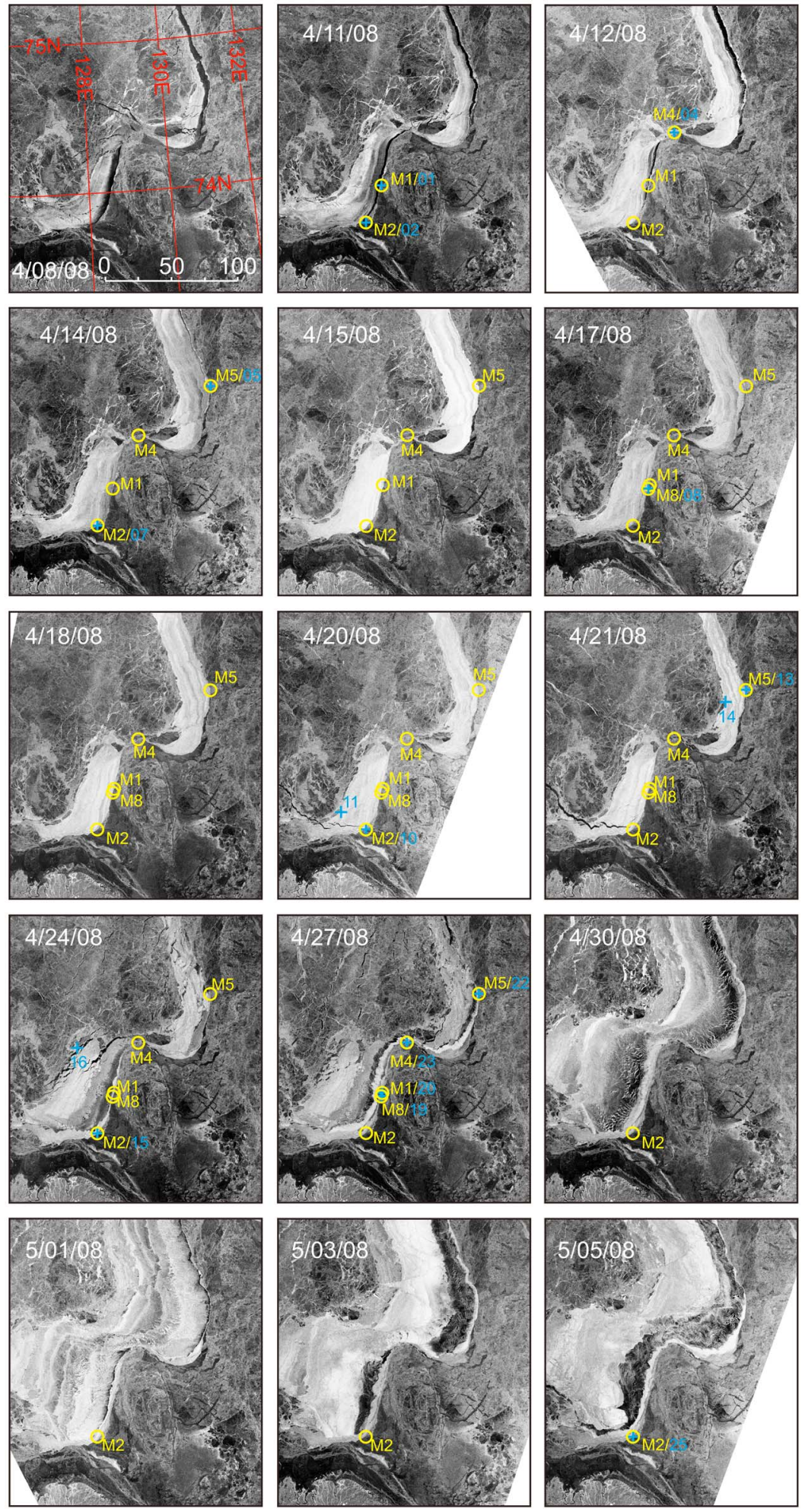

Figure 6. The ENVISAT ASAR satellite imagery from 8 April to 5 May shows the evolution of the West New Siberian (WNS) coastal polynya. Numbered blue crosses indicate CTD stations. Yellow circles show mooring positions.

openings (Figures $7 \mathrm{~b}, 7 \mathrm{c}, 10 \mathrm{a}$, and $10 \mathrm{~b}$ ) that result in bottom layer cooling and freshening with further return to the equilibrium conditions. It seems that there was the inflow of warm and saline water to reestablish this equilibrium. The temperature and salinity records are consistent with a bottom thermohaline frontal zone located to the north and approaching M1 from the northerly directions. We found no thermohaline signature of polynya sea ice formation (cooling 


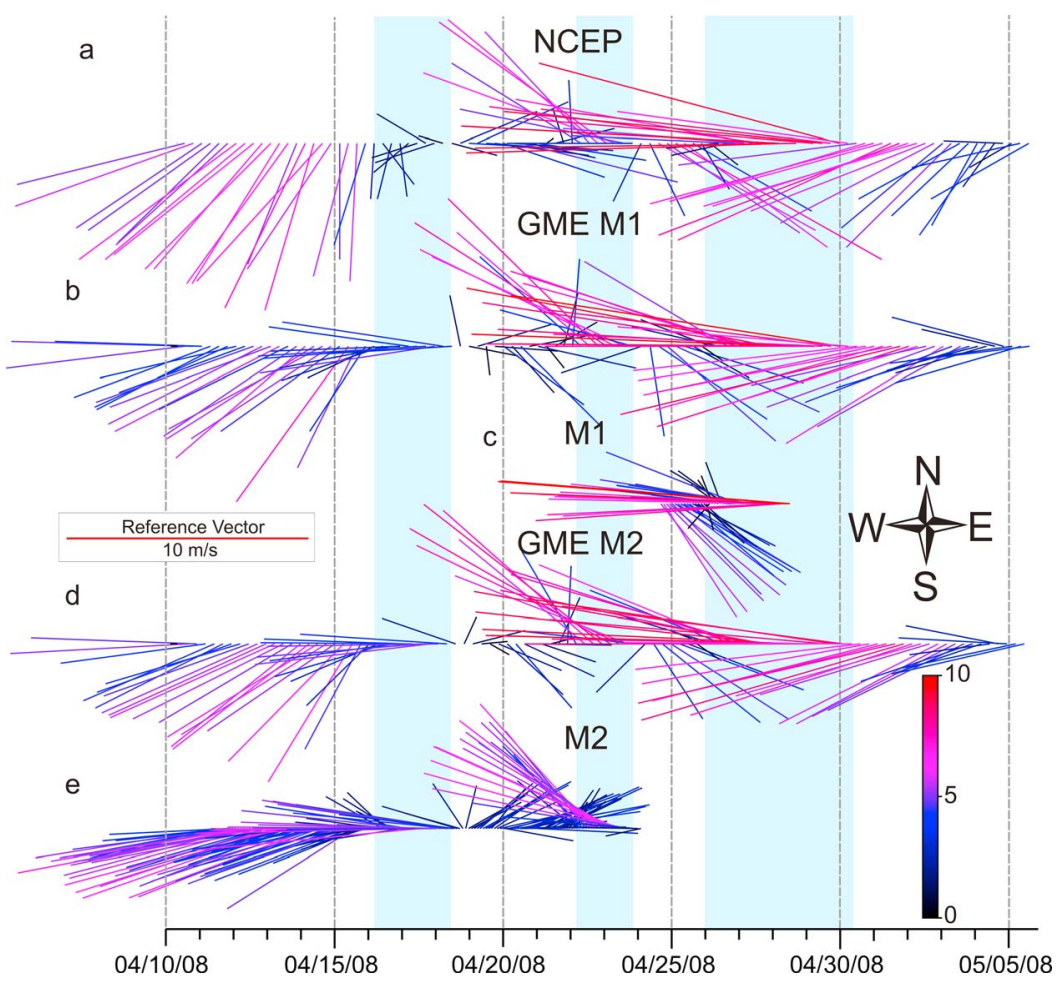

Figure 7. The stickplots of wind over the Laptev Sea coastal polynya. The length, color, and direction of each stick give the magnitude $(\mathrm{m} / \mathrm{s})$ and direction (degree) of two-hour mean wind vector (true north is upward). (a) The National Centers for Environmental Prediction (NCEP) wind at $75^{\circ} \mathrm{N}$ and $125.5^{\circ} \mathrm{E}$, (b) GME wind at M1, (c) AWS wind record at M1, (d) GME wind at M2, and (e) AWS wind record at M2. The periods of polynya favorable easterly-southeasterly wind are highlighted with blue shading.

and salinification) at the bottom layer temperature and salinity. Instead, during two polynya events in the second part of April the thermohaline signature of warmer and saltier water inflow keeps its identity, and the bottom layer hydrography similarly responds to all three polynya-favorable wind events regardless of polynya opening. Note that among the three polynya-favorable wind events only the last one resulted in substantial polynya opening (Figure 6). One

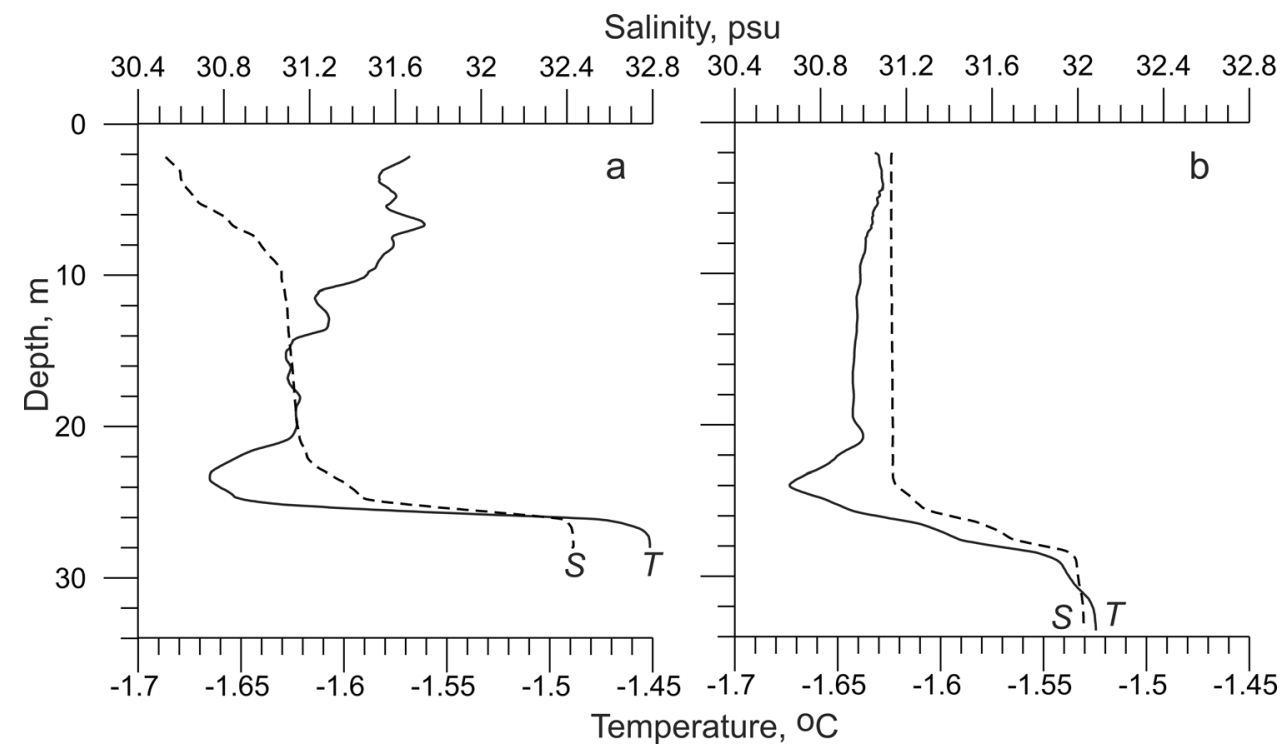

Figure 8. Vertical profiles of temperature (solid line, ${ }^{\circ} \mathrm{C}$ ) and salinity (dashed line, psu) taken over the offshore perimeter of the WNS coastal polynya from the pack ice at (a) station 14 and (b) station 16 demonstrate warmer and saltier water intrusions near the bottom (see Figure 6 for station positions). 


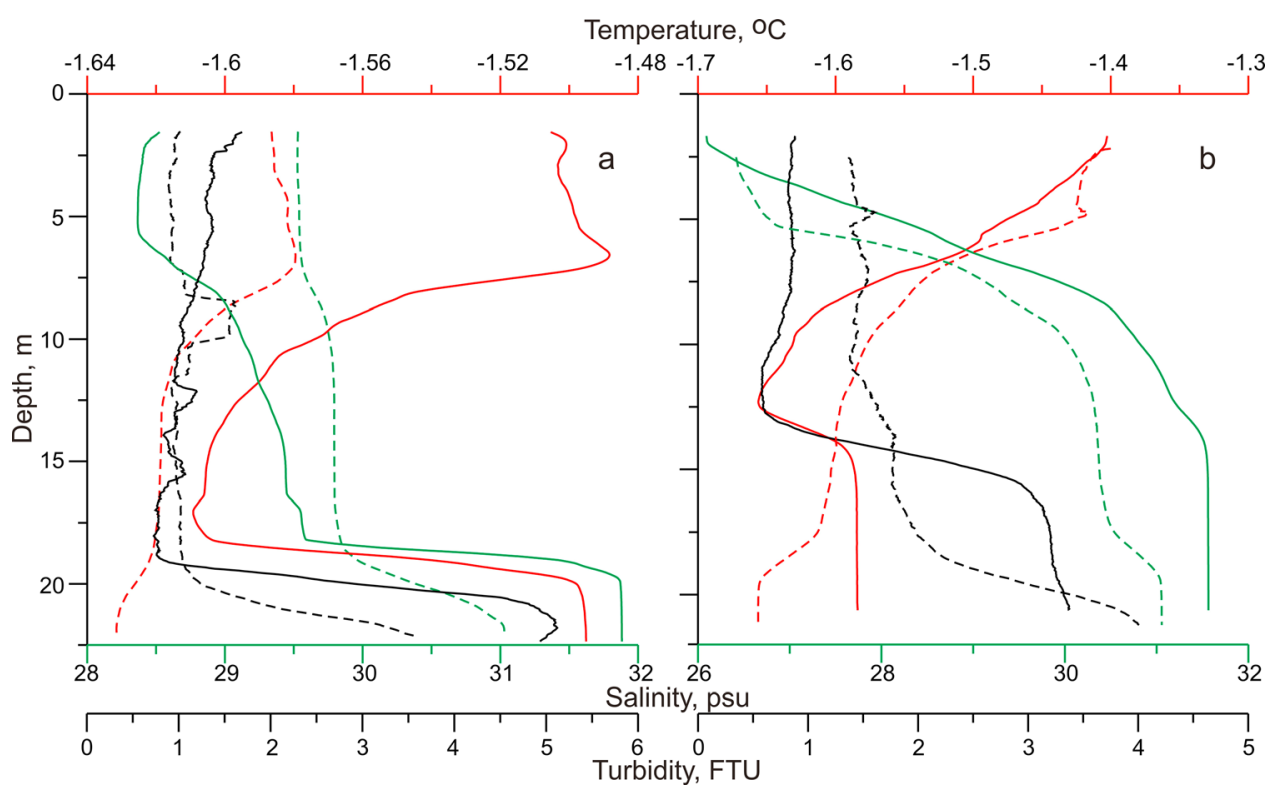

Figure 9. Vertical profiles of temperature (red lines, ${ }^{\circ} \mathrm{C}$ ), salinity (green lines, psu), and turbidity (black lines, Formazin Turbidity Units (FTU)) at moorings (a) M1 and (b) M2, contouring the onshore perimeter of the coastal polynya. CTD casts were taken at M1 on station 1 (10 April, dashed line) and station 20 (28 April, solid line) and at M2 on station 15 (24 April, dashed line) and station 25 (5 May, solid line).

may speculate that the bottom layer cooler and fresher anomalies in Figure 10a can be also attributed to the entrainment of a cooler and fresher surface layer into the underlying warmer and saltier bottom layer at vertical mixing driven by brine rejection at polynya events. However, this is not in agreement with surface layer SBE 37 CTD record (not shown) that demonstrates no salinity increase triggering vertical mixing at polynya-favorable wind events shown in Figure 10.

[31] While being separated only by $33 \mathrm{~km}, \mathrm{M} 2$ exhibited a substantially different thermohaline signature with warmer and saltier bottom water signal that approached M2 from the southwest only at 29 April, lagging M1 by 16 days. Two polynya-favorable wind events result in bottom layer cool-

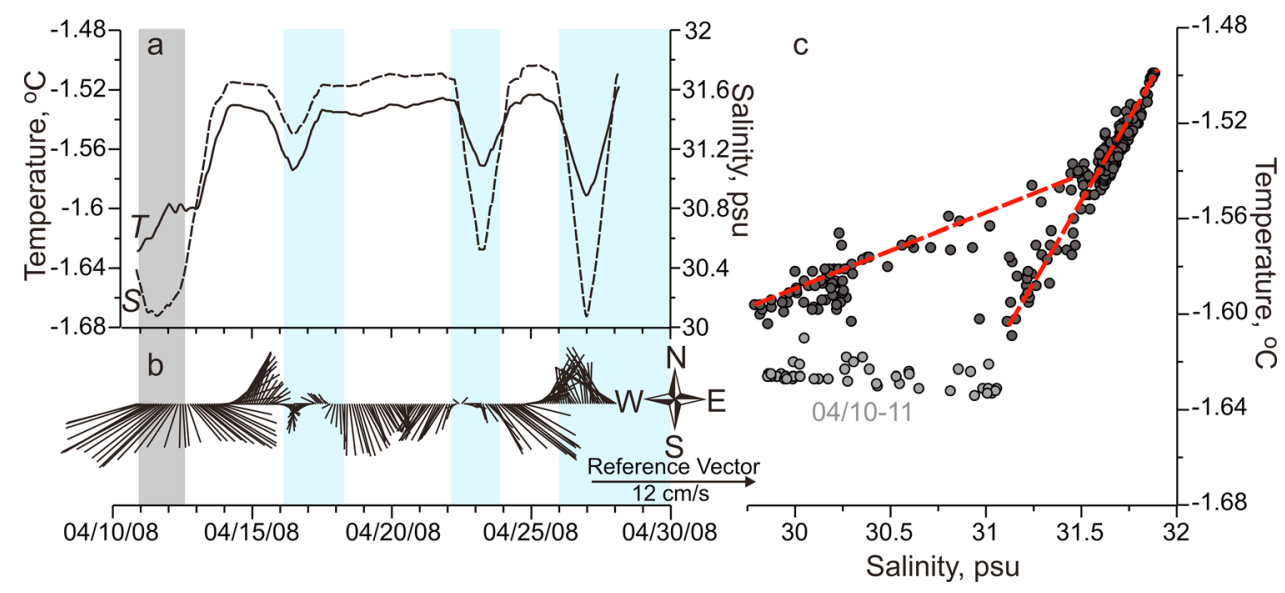

Figure 10. The M1 mooring time series for the bottom layer for 10-27 April, 2008. (a) Twenty-four hour mean time series of salinity (dashed line, psu) and temperature (solid line, ${ }^{\circ} \mathrm{C}$ ) from $21 \mathrm{~m}$, and (b) stickplots of low-passed currents from the lowest depth Acoustic Doppler Current Profiler (ADCP) bin at $17.5 \mathrm{~m}$. The length and direction of each stick gives the magnitude $(\mathrm{cm} / \mathrm{s})$ and direction (degree) of two-hour mean current (true north is upward). The portion of negatively correlated temperature and salinity is highlighted with gray shading. The periods of polynya-favorable southeasterly wind are highlighted with blue shading. (c) Temperature-salinity scatterplot of the one-hour mean temperature and salinity time series from $21 \mathrm{~m}$ at the M1 mooring. Gray dots depict temperature-salinity characteristics for 10-11 April 2008. The upwelling/downwelling lines are shown in red and dashed. 


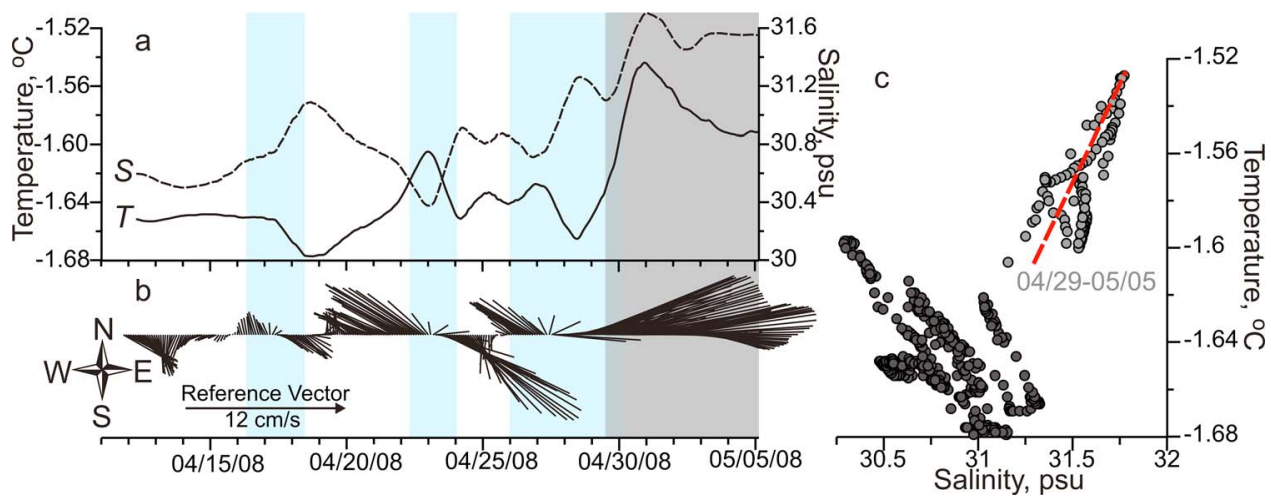

Figure 11. The M2 mooring time series for the bottom layer for 11 April to 5 May 2008. (a) Twentyfour hour mean time series of salinity (dashed line, psu) and temperature (solid line, ${ }^{\circ} \mathrm{C}$ ) from $19 \mathrm{~m}$, and (b) stickplots of low-passed currents from the lowest-depth ADCP bin at $17.5 \mathrm{~m}$. The length and direction of each stick gives the magnitude $(\mathrm{cm} / \mathrm{s})$ and direction (degree) of two-hour mean current (true north is upward). The portion of positively correlated temperature and salinity is highlighted with gray shading. The periods of polynya-favorable southeasterly wind are highlighted with blue shading. (c) Temperaturesalinity scatterplot of the one-hour mean temperature and salinity time series from $19 \mathrm{~m}$ at the M2 mooring. Gray dots depict temperature-salinity characteristics for 29 April 29 to 5 May 2008. The upwelling/ downwelling line is shown in red and dashed.

ing and salinification (Figure 11a). The negative correlation between temperature and salinity (until 29 April) suggests that before the end-of-April polynya event sea ice formation plays a key role in setting hydrographic conditions in this location (Figures 7d, 7e, 11a, and 11c). Afterward, when temperature and salinity increased by $0.5^{\circ} \mathrm{C}$ and $1.2 \mathrm{psu}$, the correlation changed sign (Figures 11a and 11c). The warming and salinification of the bottom layer at the end of April is consistent with southeasterly flow (up to $12-13 \mathrm{~cm} / \mathrm{s}$, Figure $11 \mathrm{~b}$ ) that was found almost uniformly from the surface to the bottom (not shown), but in opposite direction to the surface wind (Figure 7d). It is very likely that this locally pervasive southeasterly flow is the result of a geostrophic adjustment to the polynya-generated density field [Dmitrenko et al., 2010]. In contrast to the end-of-April polynya event, the surface under-ice flow at both mooring locations is consistent with the mean wind forcing, tending to flow $\sim 5^{\circ}$ $35^{\circ}$ to the right of the surface wind vector [Dmitrenko et al., 2010]. The bottom flow demonstrates patterns consistent with currents directed opposite to the surface under-ice flow (not shown).

\section{Discussion: The Impact of the Arctic Ocean Atlantic Water Layer on the Laptev Sea Shelf}

[32] In this section we combine our inferences from the historical data, 2008 shelf observations, and 2002-2009 cross-slope data (Figures 12 and 13) to emphasize the role of the AW in modifying the shelf water properties and to develop a conceptual understanding of the Atlantic water impact on the shelf. Finally, we discuss our results in the context of climatic change and stability of submarine permafrost and permafrost-related gas hydrate stability zone.

[33] As previously indicated, the bottom layer displays thermohaline characteristics that differ from those of the ambient water, implying that it was created at another location where different temperature and salinity character- istics prevail. We argue that the Laptev Sea continental slope observations (Figure 12) provide evidence that the warm and saline bottom water observed over the shelf originates from the continental slope. Annual 2002-2009 cross-slope temperature section (Figure 12) in general corroborates our results obtained from historical hydrographic data. The cross-slope sections taken in 2002 and again in 2003 demonstrate no substantial difference, while the occupation in September 2004 exhibits a dramatic change in AW layer temperature and thickness [Figure 12, see also Dmitrenko et al., 2008c]. From 2003 to 2007-2008 the AW core warming reached $\sim 1^{\circ} \mathrm{C}$, complementing the AW core temperature-time series by Polyakov et al. [2004] with the latest warming event. The AW warming tendency of mid-2000s is consistent with outer shelf bottom temperature variability that exhibits temperature maximums in the mid-2000s and also in the mid-1990s (Figure 5). As of the mid-2000s, the outer shelf warming event of the mid-1990s is similarly attributed to the strong warming within the AW layer reported by Quadfasel et al. [1991], Woodgate et al. [2001], and Schauer et al. [2002]. While during April-May the AW layer is the only source of heat over the Laptev Sea mid and outer shelves, the substantial difference between the thermohaline characteristics of the warm and saline bottom water intrusions (from $-1.45^{\circ} \mathrm{C}$ to $-1.50^{\circ} \mathrm{C}$ and from 31.5 to 32.5 psu, Figures $8,9,10$, and 11$)$ and the AW layer $\left(>0^{\circ} \mathrm{C}\right.$ and $34.6 \mathrm{psu}$ ) allows no direct attribution of the observed warm and saline shelf bottom water to the AW layer. This raises the question: where is this water coming from?

[34] Our climatology (Figure 2) demonstrates that the warm AW is usually shifted off-slope, so that the mean continental slope bottom temperature never exceeds $-0.2^{\circ} \mathrm{C}$ (Figures $2 \mathrm{c}$ and $2 \mathrm{~d}$ ) with a standard deviation of $\pm 0.5^{\circ} \mathrm{C}$ (not shown). The CTD cross-slope transect shown in Figure 12 partly corroborates this conclusion, however the coarse spatial resolution over the continental slope allows no consistent conclusions to be made. Figure 12 also suggests that 


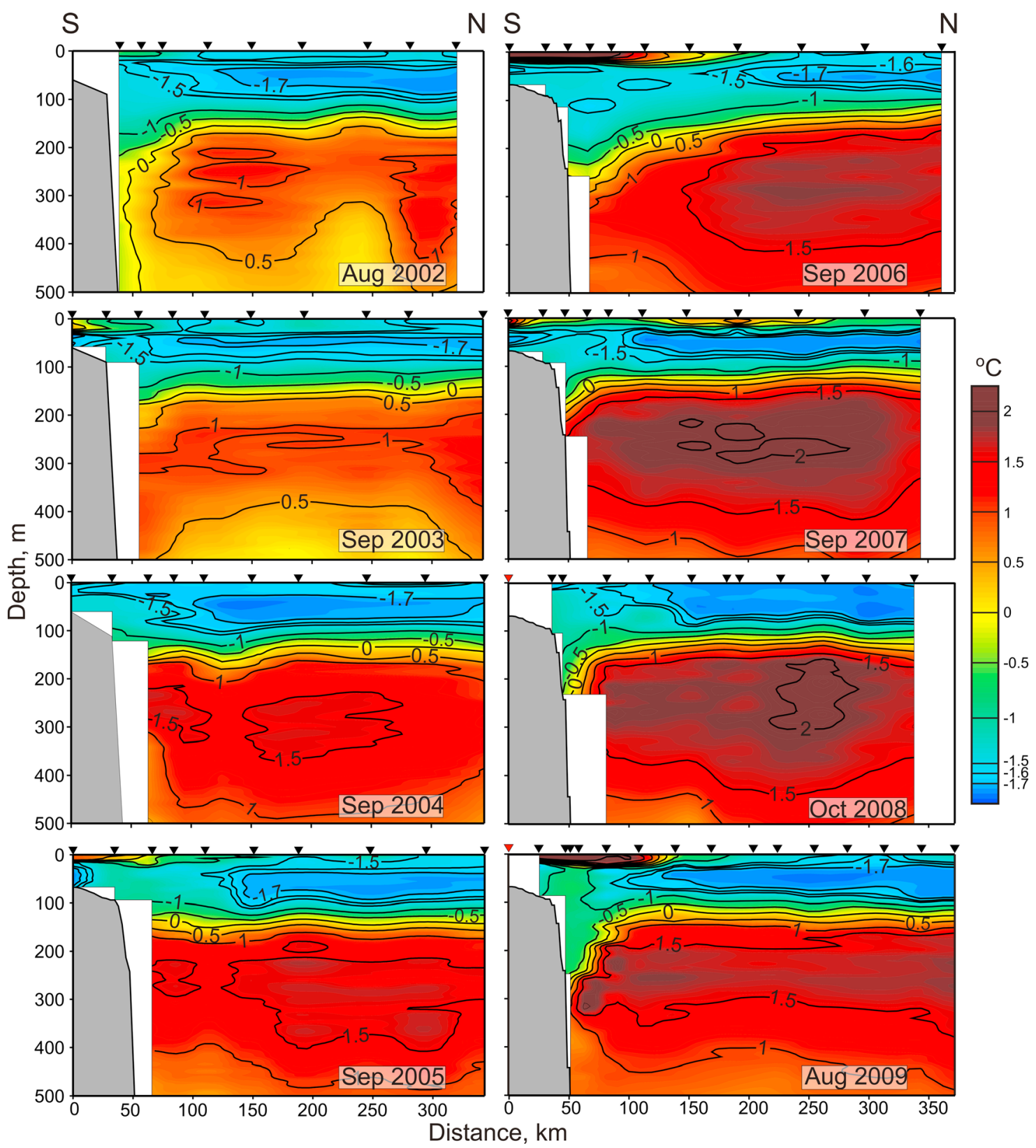

Figure 12. The $10 \mathrm{~m}$ binned temperature $\left({ }^{\circ} \mathrm{C}\right)$ cross-slope section taken in August-October 2002-2009 across the central Laptev Sea continental slope following $126^{\circ} \mathrm{E}$ (for location see Figures $2 \mathrm{a}$ and $2 \mathrm{~b}$ ). Black arrows on the top show the CTD stations. Red arrows indentify position of CTD stations shown in Figure 13. Blank areas represent missing data.

heat is lost from the AW and gained by the overlying lowhalocline water (LHW) explicitly over the continental slope area. For example, temperatures from the southern portion of the Laptev Sea cross-slope transect were $0.3^{\circ} \mathrm{C}-0.7^{\circ} \mathrm{C}$ higher at $50-75 \mathrm{~m}$ water depth compared to temperatures taken at the same depth further north on the section (Figure 12). The cross-slope observations from 2008 and 2009 provide the best examples for this upward flux of Atlantic heat to the overlaying LHW water at the continental slope. Moreover, in both years warm and saline bottom layer intrusions have been observed in September over the transitional zone between the mid and outer shelves at the southern termination of the NABOS cross-slope transect (Figure 13). We speculate that the lateral on-shore transport of the warmer and saline LHW modified by the upward flux of AW heat over the continental slope results in bottom temperature inversions recorded over the Laptev Sea shelf. This conclusion is in agreement with stable oxygen isotope data from April to May 2008. This data exhibits a relatively low bottomlayer fraction of both brine water attributed to sea ice formation and river runoff water attributed to vertical mixing with a surface-freshened layer (D. Bauch, personal communication, 2009) that confirms remote origin of the warm and saline bottom layer anomaly.

[35] Focus upon the probable source of the warm and saline bottom water also requires consideration of possible 


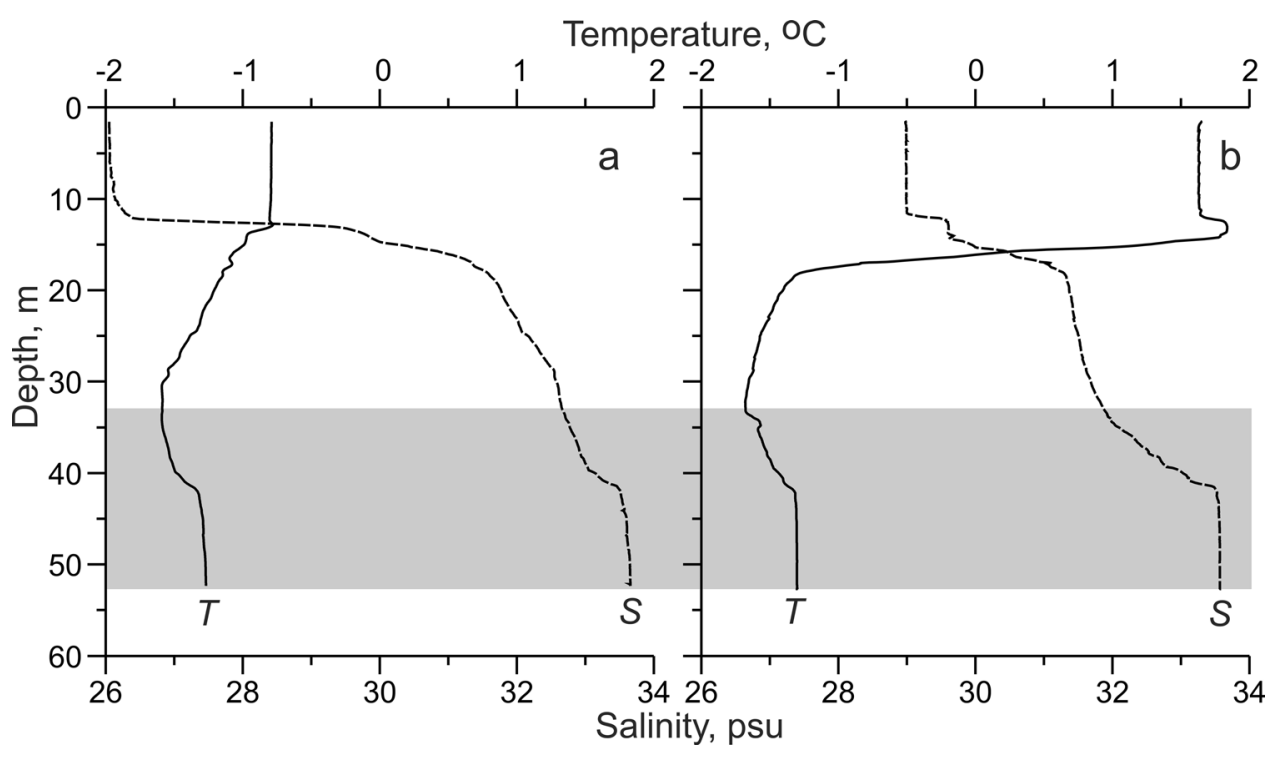

Figure 13. Vertical profiles of temperature (solid line, ${ }^{\circ} \mathrm{C}$ ) and salinity (dashed line, psu) taken over the Laptev Sea outer shelf at $76.34^{\circ} \mathrm{N}$ and $126.06^{\circ} \mathrm{E}$ in (a) September 2008 and (b) September 2009 (for station positions see Figure 12). The warmer and saltier bottom layer is highlighted with gray shading.

generation mechanisms. The on-shelf upwelling of the AW is commonly observed over the western Arctic Ocean continental margins (for overview see Pickart et al. [2009]). Dmitrenko et al. [2006] reported cross-slope wind-driven seasonal displacement of the AW jet. Over the northeastern Laptev Sea, winds have an offshore component from October to April, while prevailing summer winds are weaker, turning along-shore toward the east in May-September [Dmitrenko et al., 2006]. At a mooring deployed at about $150 \mathrm{~km}$ north off the continental shelf break the on-slope shift of the warmer AW jet was observed in response to off-slope (winter) wind, while the along-slope (summer) wind results in cooling due to off-slope AW core movement. The average range of temperature anomalies related to seasonal change in wind patterns was estimated to be $\pm 0.3^{\circ} \mathrm{C}$ for the upper boundary of the AW layer (130-160 m). This is consistent with our historical data demonstrating (1) nearly the same range of bottom temperature anomaly and (2) seasonal difference in warm and saline water on-shore extension (Figures 3c and 3d). On the basis of a one-year mooring record (1998-1999) from the Laptev Sea eastern mid shelf (44 m), Dmitrenko et al. [2001] reported a bottom temperature increase of $0.3^{\circ} \mathrm{C}$ associated with on-shore upwelling bottom currents up to $59 \mathrm{~cm} / \mathrm{s}$. They were also the first to infer the inflow of warm and saline water onto the Siberian shelf on the basis of several CTD profiles taken at the vicinity of a mooring in August 1998 and May 1999 (Figure 14b). Wegner et al. [2005] also reported bottom sediment resuspension in response to these upwelling events that is consistent with our observations of the bottom nepheloid

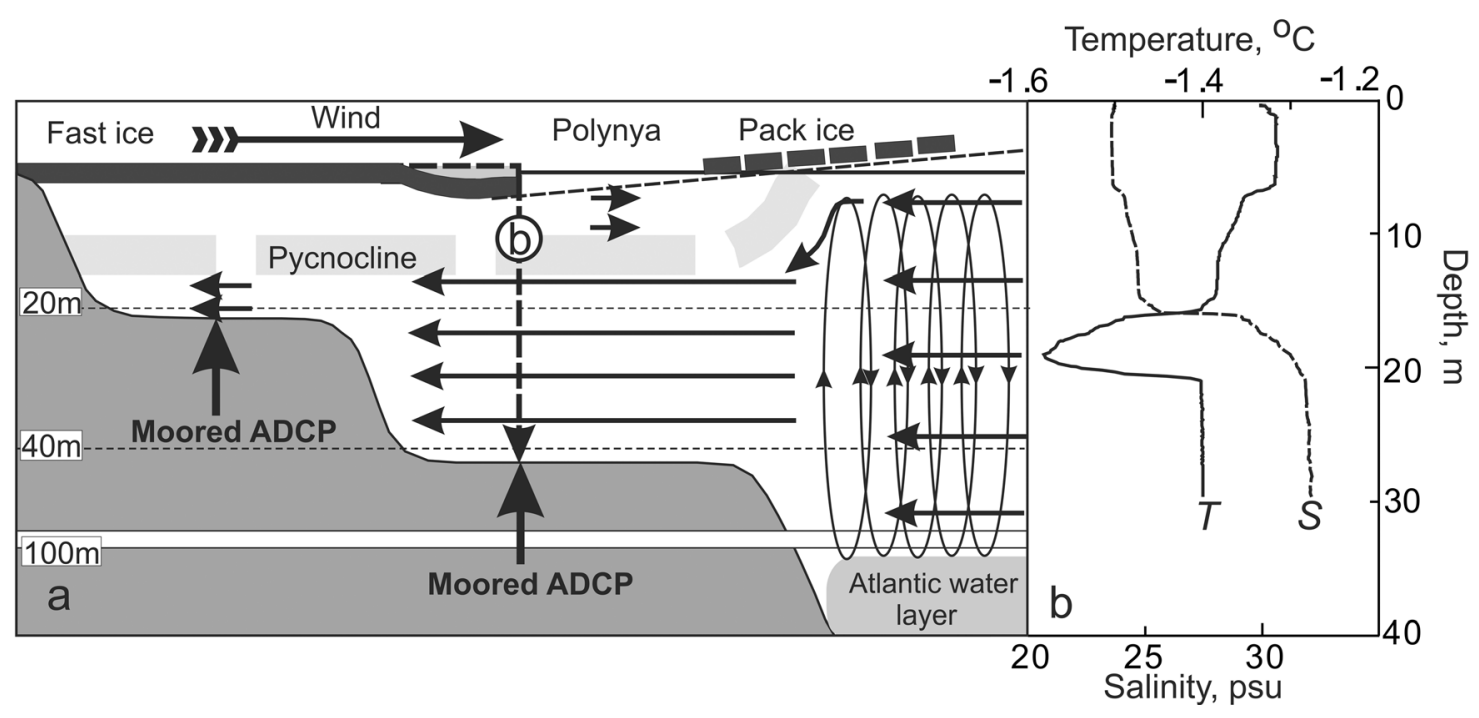

Figure 14. (a) Schematic drawing of Atlantic water impact on the shelf with (b) CTD profile taken in May 1999 near the fast ice edge in the eastern Laptev Sea following Dmitrenko et al. [2001]. 
layer (Figure 9). These rather scarce observations allowed, however, Dmitrenko et al. [2001] to draw schematic depiction of the AW impact on the shelf shown in Figure $14 \mathrm{a}$, emphasizing coincidence of polynya openings with upwelling events and speculating on the role of upward heat flux from the AW northward over the continental slope.

[36] We argue that there is compelling evidence partly supporting the schematic drawing in Figure 14a. First, the CTD section in Figure 12 demonstrates cross-slope temperature distribution highly suggestive of enhanced upward heat flux from the AW over the slope supporting the schematic drawing in Figure 14. This is in line with October 2008 microstructure observations that show enhanced turbulent dissipation and mixing over the Laptev Sea continental shelf break with upward heat flux of 5-10 W/m much more than the boundary current values of $\sim 1 \mathrm{~W} / \mathrm{m}^{2}$ further north (Y.-D. Lenn, personal communication, 2009). Second, M2 reveals the impact of coastal polynya sea ice formation on the bottom layer hydrography (Figure 11a). In addition, stations 13 and 22 taken at the M5 mooring location provide evidence of the bottom layer heat release to the atmosphere. While station 13 (21 April 2008, Figure 6) exhibits warm and saline bottom water anomaly, station 22 taken 8 days later after the polynya event of 22-23 April shows a completely mixed water column (not shown) implying the role of vertical mixing occurred at coastal polynya areas in the ventilating bottom layer as well as bottom layer heat upward flux to the atmosphere. However, the portion of the AW heat that may be released to the atmosphere this way is rather insignificant. For example, the heat content of the bottom layer highlighted with gray shading in Figure 13 is about 35-36 $\mathrm{MJ} \mathrm{m}^{-2}$, that is, more than 300 times less than the AW layer heat content off the Laptev Sea continental slope in 2009 (about 12,000 $\mathrm{MJ} \mathrm{m}^{-2}$ ).

[37] However, the role of AW upwelling onto the Laptev Sea shelf still remains rather unclear. Both historical data from the mid and outer shelves and the April-May 2008 mooring record from the inner shelf indicate the winddriven patterns of the bottom layer dynamics. However, the outer shelf bottom temperature and local zonal wind over the Laptev Sea continental slope exhibit positive correlation that implies the wind-driven on-shelf Ekman transport of the warmer (and saline, not shown) LHW modified by the enhanced vertical mixing with underlying AW over the continental slope rather than direct upwelling of the AW onto the shelf. This mechanism is consistent with winddriven transport of the LHW on to the Chukchi Sea shelf reported by Woodgate et al. [2005]. We also derived no dynamical patterns that are consistent with southward upwelling of the outer shelf bottom thermohaline anomalies. Instead, the pathways of the warm and saline water anomalies are primarily affected by their spatial distribution over the shelf, as evident from M1 and M2 records (Figures 10 and 11).

[38] Recent measurements made in the Laptev Sea mid shelf, however, also show warmer bottom water masses maintained by wind-forced vertical mixing events, which occurred during the fall. These newly obtained records also demonstrate that the bottom water layer may sustain positive temperature anomaly until the end of March [Hölemann et al., 2010]. In contrast to our results, this bottom water exhibits warmer and fresher anomaly relative to the initial summer conditions. However, a possible lateral advection of this mid shelf water mass toward our area of investigation may result in warmer and saltier anomalies relative to the overlaying water, preventing at this point a clear attribution of the inner shelf change in hydrography to AW incursions.

[39] Finally, we discuss the results in the context of issues arisen from climatic changes which occurred in the area. First, the sea ice retreat from the Laptev Sea shelf during summer is observed since 2005 [Kwok et al., 2009]. On the basis of numerical simulation, Carmack and Chapman [2003] suggest an abrupt onset of shelf break upwelling when the ice edge retreats beyond the shelf break. We argue that this pattern is not in agreement with our record. For example, the bottom temperature-time series from the outer shelf exhibits the mid-2000s maximum that may be attributed to the sea ice retreat (Figure 5). However, this maximum is similar to that of the mid-1990s when no ice edge retreat beyond the shelf break was observed (Figure 5). Second, since the mid-1980s the summer air temperature over the eastern Siberian shelf area exhibits a tendency to increase [e.g., Comiso, 2003; Overland et al., 2004]. This underlies speculations on the thawing of the eastern Siberian shelf offshore relic permafrost due to the rapid increase of the overlying shelf water temperature [Shakhova et al., 2009]. In addition, Shakhova and Semiletov [2009] suggest the degradation of terrestrial permafrost that leads to increasing river runoff, which warms the shelf water, which, in turn, transports heat down to shelf sediments and subsea permafrost. In contrast to these speculations, for the Laptev Sea mid and outer shelves we find no linkage between the surface air temperature and river discharge and the bottom water layer temperature. In fact, over the Laptev Sea mid and outer shelves the mean bottom water temperature varies from $-1.45^{\circ} \mathrm{C}$ to $-1.64^{\circ} \mathrm{C}$ (Figures $2 \mathrm{c}, 2 \mathrm{~d}, 3 \mathrm{c}, 3 \mathrm{~d}$ ) with standard deviation between $0.07^{\circ} \mathrm{C}$ (Figure $3 \mathrm{c}$ ) and $0.50^{\circ} \mathrm{C}$ (Figure 3d). Over the last 75-year period only the outer shelf temperature exhibits a slightly positive tendency of $\sim 0.15^{\circ}$ $\mathrm{C}$, mostly because of two AW warming events from the mid-1990s to 2000s (Figure 4c). The typical range of the bottom temperature increase associated with lateral northerly flow of warm and saline water from the continental slope is about $0.2^{\circ} \mathrm{C}-0.5^{\circ} \mathrm{C}$ (Figures $8,9,10,11$, and 13). Overall, these thermal conditions favor the stability of offshore relic permafrost because thawing from the top (i.e., from the seafloor downward) does not occur or occurs very slowly at bottom water temperatures below zero [Romanovskii et al., 2005]. So there is no hydrographic reason to expect thawing of offshore relic permafrost as suggested by Shakhova et al. [2009] and Shakhova and Semiletov [2009]. An exception is observed only near the coastline and shoals shallower than 10-12 m, where the seawater during summer is above zero temperature (Figure 2d). Only in these areas, slow thawing of relic permafrost is possible [Romanovskii et al., 2005].

\section{Conclusions}

[40] The purpose of this paper is to examine the role of the AW in modifying the Laptev Sea shelf bottom hydrography. A climatology (1932-2008) of bottom hydrography from the Siberian shelf of the Laptev Sea provides evidence of warming that extends northward from the transitional zone 
between the mid and outer shelves (Figure 2). Bottom layer temperature and AW core temperature-time series both compiled from historical data clearly link the outer shelf to the AW boundary current transporting warm and saline water from the North Atlantic downstream along the Eurasian continental margins (Figure 5). The AW warming tendency of the mid-1990s to the mid-2000s is consistent with outer shelf bottom temperature variability. For winter 2008 we found numerous evidences of the wind-driven on-shelf warm and saline water intrusions, even to the depths of the inner shelf of about $20 \mathrm{~m}$. These intrusions are typically $\sim 0.2^{\circ} \mathrm{C}$ warmer and $\sim 1-1.5$ psu saltier than ambient water (Figures 8, 9, 10, and 11). This is also in agreement with a mean range of northward temperature and salinity increase over the mid and outer shelves derived from the temperature-depth and salinity-depth scatterplots in Figure 3. The 2002-2009 cross-slope observations provide a strong evidence of existence of the continental slope upward heat flux from the AW to the overlying LHW. With the AW layer as the only source of heat over the outer shelf, the lateral onshore wind-driven Ekman transport of the low-halocline continental slope water modified because of the upward flux of AW heat results in bottom layer anomalies recorded over the Laptev Sea shelf. We also found that polynya-induced vertical mixing may act as a drainage of bottom heat anomaly finally permitting a relatively small portion of the AW heat to be directly released to the atmosphere.

[41] Our results also have important implications for environmental change under scenarios of altered climate. Over the mid and outer shelves we found no substantial changes in the bottom layer thermal conditions that seem critical for stability of offshore relic submarine permafrost, but since these relatively small temperature changes are positively correlated with salinity changes, detailed studies are needed to further investigate the combined effect of temperature and salinity increases on the stability of the submarine permafrost. Future climate change may bring more intrusions of Atlantic-modified waters onto the shelf with potentially warmer temperatures, which could have a critical impact on the stability of relic offshore submarine permafrost.

[42] While we focus on the Siberian shelf of the Laptev Sea, we believe the analysis is applicable to the entire eastern Siberian shelf.

[43] Acknowledgments. Financial support through the BMBF projects System Laptev Sea (I.A.D., J.A.H., T.K., H.K., G.H., and D.S.), Otto Schmidt Laboratory for Polar and Marine Sciences (S.K., J.A.H., H.K.), and the Deutsche Forschungsgemeinschaft (DFG) (D.B. and C.W.) is gratefully acknowledged. B.T. was supported by the Natural Sciences and Engineering Research Council of Canada Discovery Grant Program and by the National Science Foundation under grant OPP-0230325 from the Office of Polar Programs and grant ARC-05-20496 from the Arctic Science Program. Torben Klagge (IFM-GEOMAR) and Alfred Helbig (University of Trier) have rendered invaluable assistance in performing oceanographic and meteorological measurements in the Laptev Sea in spring 2008. The cross-slope hydrographic observations in 2002-2009 were carried out within the working framework of the ongoing NOAA and NSF-funded IARC Program Nansen and Amundsen Basins Observational System (NABOS). We gratefully acknowledge Andrey Novikhin (AARI) for CTD profiles taken in 2008-2009 from the R/Vs Ivan Kireev and Yakov Smirnitsky. We are grateful to Igor Polyakov (University of Alaska Fairbanks, United States) and Louis Fortier (Laval University, Canada) for borrowing the oceanographic equipment for the 2008 field campaign. We appreciate Rebecca Woodgate (University of Washington) and Leo Timo- khov (AARI) for their helpful comments and discussions. GME data were kindly provided by the German Meteorological Service.

\section{References}

Aagaard, K. (1989), A synthesis of the Arctic Ocean circulation, Rapp. P.-V. Reun. Cons. Int. Explor. Mer, 188, 11-22.

Bareiss, J., and K. Görgen (2005), Spatial and temporal variability of sea ice in the Laptev Sea: Analyses and review of satellite passive-microwave data and model results, 1979 to 2002, Global Planet. Change, 48(1-3), 28-54.

Bauch, D., I. Dmitrenko, S. Kirillov, C. Wegner, J. Hölemann, S. Pivovarov, L. Timokhov, and H. Kassens (2009a), Eurasian Arctic shelf hydrography: Exchange and residence time of southern Laptev Sea waters, Cont. Shelf Res., 29, 1815-1820, doi:10.1016/j.csr.2009.06.009.

Bauch, D., I. A. Dmitrenko, C. Wegner, J. Hölemann, S. A. Kirillov, L. A. Timokhov, and H. Kassens (2009b), Exchange of Laptev Sea and Arctic Ocean halocline waters in response to atmospheric forcing, J. Geophys. Res., 114, C05008, doi:10.1029/2008JC005062.

Carmack, E., and D. C. Chapman (2003), Wind-driven shelf/basin exchange on an Arctic shelf: The joint roles of ice cover extent and shelf-break bathymetry, Geophys. Res. Lett., 30(14), 1778, doi:10.1029/2003GL017526.

Comiso, J. C. (2003), Warming trends in the Arctic from clear sky satellite observations, J. Clim., 16(21), 3498-3510, doi:10.1175/1520-0442 (2003)016.

Comiso, J. C., C. L. Parkinson, R. Gersten, and L. Stock (2008), Accelerated decline in the Arctic sea ice cover, Geophys. Res. Lett., 35, L01703, doi:10.1029/2007GL031972.

Dickson, R. R., T. J. Osborn, J. W. Hurrell, J. Meincke, J. Blindheim, B. Adlandsvik, T. Vinje, G. Alekseev, and W. Maslowski (2000), The Arctic Ocean response to the North Atlantic Oscillation, J. Clim., 13(15), 2671-2696, doi:10.1175/1520-0442(2000)013<2671:TAORTT $>2.0$. $\mathrm{CO} ; 2$.

Dmitrenko, I. A., J. A. Hoelemann, S. A. Kirillov, S. L. Berezovskaya, and H. Kassens (2001), Role of barotropic sealevel changes in current formation on the eastern shelf of the Laptev Sea, Dokl. Earth Sci., 377(2), 243-249.

Dmitrenko, I. A., I. V. Polyakov, S. A. Kirillov, L. A. Timokhov, H. L. Simmons, V. V. Ivanov, and D. Walsh (2006), Seasonal variability of Atlantic water on the continental slope of the Laptev Sea during 2002 2004, Earth Planet. Sci. Lett., 244(3-4), 735-743, doi:10.1016/j. eps1.2006.01.067.

Dmitrenko, I. A., S. A. Kirillov, and L. B. Tremblay (2008a), The longterm and interannual variability of summer fresh water storage over the eastern Siberian shelf: Implication for climatic change, J. Geophys. Res., 113, C03007, doi:10.1029/2007JC004304.

Dmitrenko, I. A., S. A. Kirillov, L. B. Tremblay, D. Bauch, and M. Makhotin (2008b), Effects of atmospheric vorticity on the seasonal hydrographic cycle over the eastern Siberian shelf, Geophys. Res. Lett., 35, L03619, doi:10.1029/2007GL032739.

Dmitrenko, I. A., I. V. Polyakov, S. A. Kirillov, L. A. Timokhov, I. E. Frolov, V. T. Sokolov, H. L. Simmons, V. V. Ivanov, and D. Walsh (2008c), Toward a warmer Arctic Ocean: Spreading of the early 21 st century Atlantic Water warm anomaly along the Eurasian Basin margins, J. Geophys. Res., 113, C05023, doi:10.1029/2007JC004158.

Dmitrenko, I. A., S. A. Kirillov, L. B. Tremblay, D. Bauch, and S. Willmes (2009), Sea-ice production over the Laptev Sea shelf inferred from historical summer-to-winter hydrographic observations of 1960s-1990s, Geophys. Res. Lett., 36, L13605, doi:10.1029/2009GL038775.

Dmitrenko, I. A., et al. (2010), Observations of supercooling and frazil ice formation in the Laptev Sea coastal polynya, J. Geophys. Res., C05015, doi:10.1029/2009JC005798.

Fofonoff, P., and R. C. Millard Jr. (1983), Algorithms for computation of fundamental properties of seawater, UNESCO Tech. Pap. Mar. Sci., 44 $53 \mathrm{pp}$

Hölemann, J. A., S. Kirillov, T. Klagge, A. Novikhin, H. Kassens, and L. Timokhov (2010), Near-bottom water warming in the Laptev Sea in response to atmospheric and sea ice conditions in 2007, Polar Research, in press.

Kwok, R., and D. A. Rothrock (2009), Decline in Arctic sea ice thickness from submarine and ICESat records: 1958-2008, Geophys. Res. Lett., 36, L15501, doi:10.1029/2009GL039035.

Kwok, R., G. F. Cunningham, M. Wensnahan, I. Rigor, H. J. Zwally, and D. Yi (2009), Thinning and volume loss of the Arctic Ocean sea ice cover: 2003-2008, J. Geophys. Res., 114, C07005, doi:10.1029/ 2009JC005312.

Majewski, D., D. Liermann, P. Prohl, B. Ritter, M. Buchhold, T. Hanisch, G. Paul, W. Wergen, and J. Baumgardner (2002), The operational global 
icosahedral-hexagonal grid point model GME: Description and high resolution tests, Mon. Weather Rev., 130, 319-338.

Martin, S., and D. J. Cavalieri (1989), Contributions of the Siberian Shelf polynyas to the Arctic Ocean intermediate and deep water, J. Geophys. Res., 94(C9), 12,725-12,738, doi:10.1029/JC094iC09p12725.

Nikolopoulos, A., R. S. Pickart, P. S. Fratantoni, K. Shimada, D. J. Torres, and E. P. Jones (2009), The western Arctic boundary current at $152^{\circ} \mathrm{W}$ Structure, variability, and transport, Deep-Sea Res., Part II, 56(17), 1164-1181, doi:10.1016/j.dsr2.2008.10.014.

Overland, J. E., M. C. Spillane, D. B. Percival, M. Wang, and H. O. Mofjeld (2004), Seasonal and regional variation of pan-Arctic surface air temperature over the instrumental record, J. Clim., 17, 3263-3282, doi:10.1175/1520-0442(2004)017<3263:SARVOP>2.0.CO;2.

Pickart, R. S. (2004), Shelfbreak circulation in the Alaskan Beaufort Sea: Mean structure and variability, J. Geophys. Res., 109, C04024, doi:10.1029/2003JC001912.

Pickart, R. S., G. W. K. Moorey, D. J. Torres, P. S. Fratantoni, R. A. Goldsmith, and J. Yang (2009), Upwelling on the continental slope of the Alaskan Beaufort Sea: Storms, ice, and oceanographic response, J. Geophys. Res., 114, C00A13, doi:10.1029/2008JC005009.

Polyakov, I. V., G. V. Alekseev, L. A. Timokhov, U. S. Bhatt, R. L. Colony, H. L. Simmons, D. Walsh, J. E. Walsh, and V. F. Zakharov (2004), Variability of the intermediate Atlantic water of the Arctic Ocean over the las 100 years, J. Clim., 17(23), 4485-4497, doi:10.1175/JCLI-3224.1.

Polyakov, I., et al. (2007), Observational program tracks Arctic Ocean transition to a warmer state, Eos Trans. $A G U, 88(40), 398$, doi:10.1029/ 2007EO400002.

Quadfasel, D., A. Sy, D. Wells, and A. Tunik (1991), Warming in the Arctic, Nature, 350, 385, doi:10.1038/350385a0

Reagan, M. T., and G. J. Moridis (2007), Oceanic gas hydrate instability and dissociation under climate change scenarios, Geophys. Res. Lett., 34, L22709, doi:10.1029/2007GL031671.

Romanovskii, N. N., H. W. Hubberten, A. Gavrilov, V. E. Tumskoy, and A. L. Kholodov (2004), Permafrost of the east Siberian Arctic shelf and coastal lowlands, Quaternary Science Reviews, 23, 1359-1369, doi:10.1016/j.quascirev.2003.12.014.

Romanovskii, N. N, H. W. Hubberten, A. V. Gavrilov, A. A. Eliseeva, and G. S. Tipenko (2005), Offshore permafrost and gas hydrate stability zone on the shelf of East Siberian Seas, Geo Mar. Lett., 25(2-3), 167-182, doi:10.1007/s00367-004-0198-6.

Rudels, B., E. P. Jones, L. G. Anderson, and G. Kattner (1994), On the intermediate depth waters of the Arctic Ocean, In: The Polar Oceans and Their Role in Shaping the Global Environment: The Nansen Centennial Volume, Geophys. Monogr. Ser., vol. 85, edited by O. M. Johannessen, R. D. Muench, and J. E. Overland, pp. 33-46, AGU, Washington, D.C. Schauer, U., B. Rudels, E. P. Jones, L. G. Anderson, R. D. Muench, G. Björk, J. H. Swift, V. Ivanov, and A.-M. Larsson (2002), Confluence and redis- tribution of Atlantic water in the Nansen, Amundsen and Makarov basins, Ann. Geophys., 20(2), 257-273.

Schauer, U., E. Fahrbach, S. Osterhus, and G. Rohardt (2004), Arctic warming through the Fram Strait: Oceanic heat transport from 3 years of measurements, J. Geophys. Res., 109, C06026, doi:10.1029/ 2003JC001823.

Shakhova, N., and I. Semiletov (2009), Methane hydrate feedbacks, In Arctic Climate Feedbacks: Global Implications, edited by M. Sommerkorn and S. J. Hassol, WWF Int. Arctic Prog., Oslo, pp. 81-92.

Shakhova, N. E., V. I. Sergienko, and I. P. Semiletov (2009), The contribution of the East Siberian shelf to the modern methane cycle, Herald Russ. Acad. Sci., 79(3), 237-246, doi:10.1134/S101933160903006X.

Stroeve, J., M. Serreze, S. Drobot, S. Gearheard, M. Holland, J. Maslanik, W. Meier, and T. Scambos (2008), Arctic sea ice extent plummets in 2007, Eos Trans. AGU, 89(2), doi:10.1029/2008EO020001.

Wegner, C., J. A. Hölemann, I. Dmitrenko, S. Kirillov, and H. Kassens (2005), Seasonal variations in Arctic sediment dynamics-evidence from 1-year records in the Laptev Sea (Siberian Arctic), Global Planet. Change, 48(1-2), 126-140, doi:10.1016/j.gloplacha.2004.12.009.

Westbrook, G. K., et al. (2009), Escape of methane gas from the seabed along the West Spitsbergen continental margin, Geophys. Res. Lett., 36, L15608, doi:10.1029/2009GL039191.

Woodgate, R. A., K. Aagaard, R. D. Muench, J. Gunn, G. Bjork, B. Rudels, A. T. Roach, and U. Schauer (2001), The Arctic Ocean boundary current along the Eurasian slope and the adjacent Lomonosov Ridge: Water mass properties, transports and transformations from moored instruments, Deep Sea Res., Part I, 48, 1757-1792, doi:10.1016/S0967-0637(00) 00091-1.

Woodgate, R. A., K. Aagaard, J. H. Swift, K. K. Falkner, and W. M. Smethie (2005), Pacific ventilation of the Arctic Ocean's lower halocline by upwelling and diapycnal mixing over the continental margin, Geophys. Res. Lett., 32, L18609, doi:10.1029/2005GL023999.

D. Bauch, I. A. Dmitrenko, H. Kassens, and C. Wegner, Leibniz Institute of Marine Sciences at University of Kiel (IFM-GEOMAR), Wischhofstr. 1-3, Kiel 24148, Germany. (idmitrenko@ifm-geomar.de)

G. Heinemann and D. Schröder, Department of Environmental Meteorology, Facultly of Geography/Geosciences, University of Trier, Behringstraße 21, Trier 54286, Germany.

J. A. Hölemann and T. Krumpen, Alfred Wegener Institute for Polar and Marine Research, Am Handelshafen 12 Bremerhaven 27570, Germany.

S. A. Kirillov, Arctic and Antarctic Research Institute, 38 Bering Str. St. Petersburg, 199397, Russia.

L. B. Tremblay, Department of Atmospheric and Oceanic Sciences, Faculty of Science, McGill University, 805 SherbrookeWest, Montreal, Quebec H3A 2K6 Canada. 